\title{
In the Name of the International: The Supreme Court of Canada and the Internationalist Transformation of Canadian Private International Law
}

\author{
Robert Wai \\ Osgoode Hall Law School of York University, rwai@osgoode.yorku.ca
}

\section{Source Publication:}

Canadian Yearbook of International Law. Volume 39 (2001), p. 117-209.

Follow this and additional works at: https://digitalcommons.osgoode.yorku.ca/scholarly_works

Part of the International Law Commons, and the Legal Profession Commons

\section{(c) $($ ) $\Theta \Theta$}

This work is licensed under a Creative Commons Attribution-Noncommercial-No Derivative Works 4.0 License.

\section{Recommended Citation}

Wai, Robert. "In the Name of the International: The Supreme Court of Canada and the Internationalist Transformation of Canadian Private International Law." Canadian Yearbook of International Law 39 (2001): 117-209.

This Article is brought to you for free and open access by the Faculty Scholarship at Osgoode Digital Commons. It has been accepted for inclusion in Articles \& Book Chapters by an authorized administrator of Osgoode Digital Commons. 


\title{
In the Name of the International: The Supreme Court of Canada and the Internationalist Transformation of Canadian Private International Law
}

\author{
ROBERT WAI
}

\section{PART 1: INTRODUCTION}

$\mathrm{G}$ lobalization and internationalization are pervasive in contemporary cultural, political, and economic policy discourses. Not surprisingly, a concern with internationalization and globalization increasingly characterizes the policy discourses of law. While the law often operates at a lag to broader social trends, it is sometimes more active in constituting such trends. This article is concerned with a striking episode of legal change oriented towards the perceived new realities of the international system, which occurred in the unlikely venue of private international law in Canada.

In a tetralogy of four cases released from 1990 to $1994,{ }^{1}$ the Supreme Court of Canada transformed the subject of private international law in terms of doctrine, policy, and overall approach. The speed and comprehensiveness of reform, change of direction in

Robert Wai, Associate Professor, Osgoode Hall Law School, York University, Toronto. This article is based on parts of an LL.M. thesis, which was submitted in 1995, and an S.J.D. dissertation, which was submitted in 2000, to Harvard Law School. My thanks for funding for graduate work that was provided by a Social Sciences and Humanities Research Council Doctoral Fellowship, a Law Foundation of British Columbia Graduate Fellowship, a Canada-US Fulbright Scholarship, and the Addison Brown Prize in Private International Law at Harvard Law School. I gratefully acknowledge the comments on relevant chapters of the dissertation by Bill Alford, Robert Howse, Kerry Rittich, and Anne-Marie Slaughter. Particular thanks to David Kennedy for his comments and for his supervision of my doctoral work at Harvard.

1 Morguard Investments Ltd. v. De Savoye, [1990] 3 S.C.R. 1077 [hereinafter Morguard]; Amchem Products Inc. v. British Columbia (WCB), [1993] i S.C.R. 897 [hereinafter Amchem]; Huntv. T $\mathcal{F}^{\circ} N$ plc, [1 1993] 4 S.C.R. 289 [hereinafter Hunt]; and Tolofson v. Jensen; Lucas (Litigation Guardian of) v. Gagnon, [1994] 3 S.C.R. 1022 [hereinafter Tolofson]. 
policy orientation, and significance for related fields such as constitutional federalism are exceptional for common law reform in Canada. While not dramatic in comparison with, for example, the promulgation of the Canadian Charter of Rights and Freedoms in $1982,{ }^{2}$ the changes are significant given that they occurred in a legal subject that is dominated by judicial rather than legislative reform and one that has tended to change incrementally, if at all. As Peter North observed just before the tetralogy was released, change in private international law in Commonwealth jurisdictions was based on "reform, but not revolution."

As notable as the doctrinal changes for the particular field of private international law are the multiple ways in which the tetralogy of Supreme Court of Canada judgments are connected to larger forces that are crucial for legal decision-making in Canada, in particular, the forces of internationalization and globalization. The effort of law-makers, including judges, to grapple with the consequences of significant levels of political, economic, cultural, and personal connections that cross national borders is a defining aspect of Canadian law-making today. The tetralogy is an excellent chance to examine the ways in which judges have responded to, and helped to shape, the processes of globalization. In particular, the tetralogy offers a striking study in judicial activism in reforming laws in the name of the international. ${ }^{4}$

The tetralogy of cases in Canada has not gone unnoticed. Both commentators and lower courts have wrestled with the significant issues broached by these cases. Moreover, there is a strong sense that the judgments constitute an unusual break in the normal activity in the field. Commentaries have proliferated, both critical and supportive, focusing on a number of angles, including the constitutional issues. ${ }^{5}$ However, less attention has been paid to the study of the role of the Supreme Court of Canada in actively instituting legal reform that responds to, and helps to construct, Canadian law in an era of globalization. ${ }^{6}$

2 Canadian Charter of Rights and Freedoms, Part 1 of the Constitution Act, 1982, being Schedule B to the Canada Act 1982 (U.K.), 1982, c. 11.

3 P. North, "Reform but Not Revolution" (1990) 220 Rec. des Cours 1.

+ For a critical assessment of Canadian policy reform instituted "in the name of globalization," see J. Laxer, False God: How the Globalization Myth Has Imperiled Canada (Toronto: Lester, 1993) at 3.

${ }^{5}$ See, for example, E. Edinger, "The Constitutionalization of the Conflict of Laws" (1995) 25 Can. Bus. L. J. 38.

${ }^{6}$ For a model examination of the crucial role of the European Court of Justice in 
The judgments of the tetralogy show how the global becomes the local in Canadian legal life. Public international lawyers and international policymakers have often overlooked private law as an important venue for diplomacy and legislation. Yet private international law cases are an example of how international concerns can "touch down" in the lives and practice of lawyers and citizens who do not specialize in international relations. Almost all practising lawyers must have some familiarity with the conflict of laws - something that is still largely untrue of subjects of public international law, such as the laws of war or the laws of international trade regulation. In addition, an understanding of the arguments concerning the international realm in the tetralogy provides useful insight to those persons who face similar international considerations in subjects such as trade law, immigration, or criminal law. ${ }^{7}$ At the most general level, the understanding of the international in the tetralogy feeds into, and evidences the importance in a particular legal field of, the debate about how Canadian society should respond to globalization and internationalization.

For scholars interested more generally in globalization, the Canadian tetralogy provides a concrete and particular study of the importance of ideas and beliefs to the reception and shaping of globalization processes. ${ }^{8}$ As common law judgments, the tetralogy

actively constructing the process of European integration, see J.H.H. Weiler, "The Transformation of Europe" (1991) 100 Yale L. J. 2403. I explore the activist role of the Supreme Court of Canada under the leadership of Justice Gérard La Forest in internationalist reform in private international law as well as in other areas of Canadian law in R. Wai, "Justice Gérard La Forest and the Internationalist Turn in Canadian Jurisprudence," in R. Johnson and J. McEvoy, eds., Gérard V. La Forest at the Supreme Court of Canada 1985-1997 (Winnipeg: Supreme Court of Canada Historical Society by the Canadian Legal History Project, 2000) 421 .

${ }^{7}$ The connection of the judgments in private international law to decisions in other areas of Canadian law is explored in. Wai, supra note 6.

* Legal studies of globalization can offer helpful detail to more amorphous and abstract studies of globalization and internationalization. From this perspective, this article is an effort to provide a "thick" description of a particular episode in the processes of globalization and internationalization, showing one venue where that process is reflected and instituted, and showing as well the connection of this episode to some of the larger social contexts and policy issues at stake in globalization. This is the approach invoked by many as the way forward for studies of globalization; see, for example, P. Cheah and B. Robbins, eds., Cosmopolitics: Thinking and Feeling beyond the Nation (Minneapolis: University of Minnesota Press, 1998). The concept of thick description is associated with the cultural anthropologist Clifford Geertz; see, for example, C. Geertz, Local Knowledge: Further Essays in Interpretive Anthropology (New York: Basic Books, 1983). 
provides the opportunity to study texts that record the ideational character of globalization as the judges attempt to provide public reasons for their decisions. These judgments therefore provide an opportunity that is not available to more general, abstract, or macro-oriented studies of globalization. ${ }^{9}$ A more detailed examination of the policy argumentation in the tetralogy with respect to international matters will hopefully bring out more clearly the manner in which the law both responds to and constructs the processes of globalization. It will also highlight some of the significant dangers and biases that might operate when internationalist reform occurs with inadequate attention to specific conditions.

To this end, the article proceeds in six stages. This introduction constitutes the first part. In the second part, the tetralogy of cases is described and the underlying policy views of the international are identified in key passages of the judgments. The third part of the article then compares two "modes" of internationalization in law - internationalization by international treaty and internationalization by "policy consciousness" - arguing that the tetralogy is a good example of the latter. The fourth part describes the main features of the overall approach to international matters contained in the tetralogy, identifying three strands of policy argumentation related to ( 1 ) an economic objective of facilitating international commerce; (2) a political objective of aiding interstate cooperation; and (3) a moral objective of promoting cosmopolitan fairness. It is then suggested that this vision of the international is similar to the vision found in three traditions of internationalism. The first tradition is the intellectual tradition of liberal internationalism, with its commitment to free trade, peaceful interstate cooperation, and cosmopolitan individualism. The second tradition is the national tradition of Canadian internationalism in

${ }^{9}$ A sense of the peculiar opportunity offered to study both the ideational and material aspects of globalization and its construction might explain the interest in fields related to private international law and international business law recently evidenced by leading figures from other disciplines who specialize in globalization such as the sociologists Pierre Bourdieu and Yves Dezalay (see, for example, P. Bourdieu, "Foreword," in Y. Dezalay and B. Garth, eds., Dealing in Virtue: International Commercial Arbitration and the Construction of a Transnational Legal Order (Chicago: Chicago University Press, 1996)), the systems theorist Gunther Teubner (see, for example, G. Teubner, ed., Global Law without a State (Aldershot, UK: Dartmouth, 1997)), and the political economist Saskia Sassen (see, for example, S. Sassen, Losing Control? Sovereignty in an Age of Globalization (New York: Columbia University Press, 1996); S. Sassen, Globalization and Its Discontents: Essays on the New Mobility of People and Money (New York: New Press, 1998)). 
national identity, foreign policy, and legal culture. The third tradition is the disciplinary tradition of international lawyers committed to the expansion of international law and institutions to preserve international order and to achieve mutually beneficial objectives such as liberal international trade.

The fifth part critically analyzes the international public policy arguments that inform the legal reforms in the cases and identifies five general dangers in the tetralogy's approach to internationalist policy argumentation. It is argued that the internationalist public policy arguments used in the tetralogy are often misunderstood and naively applied by legal decision-makers, such as lower courts who must wrestle with the legacy of the tetralogy while lacking significant experience in addressing international affairs. At certain points in the tetralogy, the Supreme Court of Canada may have itself overstated the nature of the policy arguments for internationalization and reached decisions that contain contestable analyses of internationalization. I will attempt to show how countervailing or alternative considerations are relevant to each of the political, economic, and moral objectives that inform the legal reforms of the tetralogy.

A focus on the Supreme Court of Canada judgments demonstrates how a particular understanding and version of internationalism can occupy the space of "the" internationalist understanding of legal reform. Internationalism, like justice or fairness or the right, is contestable discursive terrain. There are in fact many internationalisms, each consisting of distinctive visions and priorities. It will be argued that the internationalist commitments in the tetralogy have controversial features, including a narrow commitment to transnational commerce, a naive understanding of interstate cooperation, and a shallow sense of cosmopolitan fairness to individuals. Although the Supreme Court of Canada judgments themselves may have used these internationalist objectives effectively in the tetralogy, in other cases these goals may be overstated and conflict with other legitimate goals, such as justice to individual parties and effective social regulation. The continuing development and usage of these cases requires a careful understanding of the nature and the limits of the vision of the international expressed in these cases. I conclude the fifth section of this article, therefore, by articulating several general cautions about using the internationalist reasoning in the tetralogy.

The article closes in its sixth section with a discussion of two specific issues in private international law in order to demonstrate 
what it would mean to have a richer discourse about international public policy in the development of Canadian private international law. While some key issues have been decided, many doctrinal issues remain to be resolved and the room for argumentation, even within seemingly settled doctrinal areas, remains very broad. A more critical approach to internationalist economic, political, and moral argumentation will hopefully encourage judges, legislators, practitioners, and commentators to deploy a more sophisticated understanding of the international system and its demands - an approach that rejects both naive internationalism and naive antiinternationalism. A legacy of sophisticated arguments about Canadian law in an international age would be still more significant than the already substantial reforms achieved by the tetralogy.

\section{Part 2: The Tetralogy of Judgments in Private InTERnational LaW at THE Supreme CourT of CANADA}

It is widely acknowledged that the field of conflict of laws in Canada, which has traditionally been very stable, is now undergoing dramatic changes. ${ }^{10}$ Legal change in this area is clearly identified with several decisions of the Supreme Court of Canada after years of limited jurisprudence from the court on conflict of laws. In particular, basic change was accomplished in a tetralogy of cases that include Morguard Investments Ltd. v. De Savoye, Amchem Products Inc. v. British Columbia (WCB), Hunt v. TENN plc, and Tolofson v. Jensen. ${ }^{11}$ In these cases, the Supreme Court of Canada effected dramatic reform in each of the main subjects of the conflict of laws: recognition and enforcement, jurisdiction, and choice of law. It also made a crucial ruling concerning the conduct of discovery in inter-jurisdictional litigation. At the same time, the court instituted two fundamental changes in approach to the subject: first, it gave constitutional status to at least some of the rules of private international law and, second, it forcefully emphasized the importance of international public policy arguments in reasoning about private international law in Canada.

The following summary of the four judgments of the Supreme Court of Canada is not focused on the doctrinal implications of the

10 See, for example, J-G. Castel, Canadian Conflict of Laws, $4^{\text {th }}$ ed. (Toronto: Butterworths, 1997) c. 2; M. Baer, et al., eds., Private International Law in Common Law Canada (Toronto: Emond Montgomery, 1997) at 4.

11 All of these cases are cited in note 1. 
decisions. ${ }^{12}$ Rather, I focus on the language used in the decisions and observe that the judgments share a common vision of the international realm, which is argued to necessitate reform of the rules of private international law, both within the Canadian federation and at the international level.

MORGUARD INVESTMENTS LTD. V. DE SAVOYE ${ }^{13}$

The Supreme Court of Canada's judgment in Morguard is the foundational judgment for contemporary private international law in Canada, and it has become one of the most-cited and influential decisions in the theory and practice of Canadian law of the last decade. Morguard addressed the common law rules for recognition and enforcement of foreign judgments in Canada. The case concerned a default judgment rendered against a British Columbia defendant in an Alberta court. The plaintiff sought recognition and enforcement of the judgment in British Columbia, while the defendant relied on the lack of jurisdiction of the Alberta court, given his lack of presence or submission. A unanimous Supreme Court of Canada rejected the defence and held that Canadian common law courts should consider only whether the other state has a "real and substantial connection" to the action. ${ }^{14}$ Morguard, thus, substantially increases the risk to defendants of following the common strategy of refusing to appear in the courts of a jurisdiction in which a plaintiff has commenced an action, thus permitting a default judgment to be made against them. ${ }^{15}$

12 This is admirably done in a number of case comments and articles, some of which are referred to in the notes following; more generally, see Castel, supra note 10 , especially c. 2.

${ }^{13}$ Morguard, supra note 1. For case commentary, see "Symposium: Recognition of Extraprovincial and Foreign Judgments" (1993) 22 Can. Bus. L. J. 1; J. Blom, "Conflict of Laws - Enforcement of Extraprovincial Default Judgments - Real and Substantial Connection: Morguard Investments Ltd. v. De Savoye" (1991) $7^{\circ}$ Can. Bar Rev. 733; P. Glenn, "Foreign Judgments, the Common Law and the Constitution: De Savoyev. Morguard Investments Ltd." (1992) 37 McGill L. J. 537.

14 Morguard, supra note 1 at $1104^{-10 .}$

15 The uncertainty generated and the lowered standard meant that it would be very difficult for counsel to advise a client not to defend abroad. Moreover, once defence was begun, it is arguable that the party could be said to have voluntarily submitted. See Blom, supra note 13 . The United States faced a similar situation at the International Court of Justice [hereinafter ICJ] in Military and Paramilitary Activities in and against Nicaragua, [1986] I.C.J. Rep. 14. The United States, by arguing on the jurisdiction point, was taken by some of the judges to have voluntarily submitted on the merits. This questionable interpretation of the nature 
The reasoning in the judgment is of special interest because the court identified some of the general policy issues that it perceived to be at stake in the area of conflict of laws. The language used has often been cited by both lower courts ${ }^{16}$ and by the Supreme Court of Canada itself in subsequent cases. ${ }^{17}$ Justice Gérard La Forest, writing for the unanimous court, observed that

[t] he common law regarding the recognition and enforcement of foreign judgments is firmly anchored in the principle of territoriality as interpreted and applied by the English courts in the 19th Century ... This principle reflects the fact, one of the basic tenets of international law, that sovereign states have exclusive jurisdiction in their own territory. As a concomitant to this, states are hesitant to exercise jurisdiction over matters that may take place in the territory of other states ... The English approach, we saw, was unthinkingly adopted by the courts of this country, even in relation to judgments given in sister provinces. ${ }^{18}$

Justice La Forest expressed serious doubts that the common law rules based on the English rules concerning recognition and enforcement of foreign judgments remained appropriate for the Canadian federation. However, he went much further by undertaking an analysis of the traditional rules of recognition and enforcement under contemporary international conditions:

Modern states, however, cannot live in splendid isolation and do give effect to judgments given in other countries in certain circumstances ... This, it was thought, was in conformity with the requirements of comity, the informing principle of private international law, which has been stated to be the deference and respect due by other states to the actions of a state legitimately taken within its territory...

... the real nature of the idea of comity, an idea based not simply on respect for the dictates of a foreign sovereign, but on the convenience, nay necessity, in a world where legal authority is divided among sovereign states of adopting a doctrine of this kind...

For my part, I much prefer the more complete formulation of the idea of comity adopted by the Supreme Court of the United States in Hitton v. Guiyot, 159 U.S. 113 (1895), at pp.163-4:

of ICJ jurisdiction has been severely criticized: see, for example, M. Reisman, Systems of Control in International Adjudication and Arbitration (Durham, NC: Duke University Press, 1992) c. 2.

${ }^{16}$ See "Symposium: Recognition of Extraprovincial and Foreign Judgments," supra note 13; J. Sullivan, "The Enforcement of Foreign Judgments in B.C. - Ten Years after Morguard" (2001) 59 The Advocate 399 .

${ }^{17}$ For example, in Amchem, supra note 1 at 913-14; Hunt, supra note 1 at $321-28$; Tolofson, supra note 1 at $1048-49$.

${ }_{18}$ Morguard, supra note 1 at 1095 . 
... "Comity" in the legal sense, is neither a matter of absolute obligation, on the one hand, nor of mere courtesy and good will, upon the other. But it is the recognition which one nation allows within its territory to the legislative, executive or judicial acts of another nation, having due regard both to international duty and convenience, and to the rights of its own citizens or of other persons who are under the protection of its laws. ${ }^{19}$

Having invoked comity as the underlying international policy behind the traditional rules concerning recognition and enforcement, Justice La Forest signalled how the policy of comity and the rules connected with it must be adapted to a new international society in which the normative, economic, and political conditions of sovereignty have changed:

The world has changed since the above rules were developed in $19^{\text {th }}$ century England. Modern means of travel and communications have made many of these $19^{\text {th }}$ century concerns appear parochial. The business community operates in a world economy and we correctly speak of a world community even in the face of decentralized political and legal power. Accommodating the flow of wealth, skills and people across state lines has now become imperative. Under these circumstances, our approach to the recognition and enforcement of foreign judgments would appear ripe for reappraisal. Certainly, other countries, notably the United States and members of the European Economic Community, have adopted more generous rules for the recognition and enforcement of foreign judgments to the general advantage of litigants. ${ }^{20}$

These extraordinary passages are among the most important statements made by Canadian courts about the nature of contemporary international society. In addition, Justice La Forest's judgment posits a strong connection between the reform of particular rules on recognition and enforcement and this vision of new international realities. Specifically, he indicates that recognition and enforcement of foreign judgments by common law courts should occur so long as there is a "real and substantial connection" between the foreign court that has given the judgment and the action. ${ }^{21}$ This test effects a more generous approach because "the most real and substantial connection is not required."22

Since the case involved two common law provinces of Canada, Justice La Forest also surveyed a range of issues related to federalism.

19 Ibid. at $1095-96$.

20 Ibid. at 1098 .

${ }^{21} \mathrm{Ibid}$. at $1108-09$. For a cautious critique of some ambiguities of this approach, see Blom, supra note 13.

${ }^{22}$ Castel, supra note 10 at 44 . 
First, he signalled that the conditions of an international society are at least as present in the federal context, namely that the movement of wealth, skills, and peoples is a social reality and an accepted objective in Canada. ${ }^{23}$ Second, he signalled that the reform of these rules would be consistent with the constitution of Canada. He cited an assortment of constitutional provisions, including mobility rights under section 6 of the Charter and the little-used federal customs union provision, section 121 of the Constitution Act, $1867 \cdot{ }^{24}$ These passages of the judgment suggested to many observers that the court was indicating that the Canadian constitution might require certain rules in the conflict of laws..$^{25}$ In the recognition and enforcement context, the judgment in Morguard seems to accept that the Canadian constitution contained provisions not unlike the US constitution's "full faith and credit" clause. ${ }^{26}$

The judgment left open several key issues. First, the exact contours of the real and substantial test were vague and were left to be developed gradually by lower courts. ${ }^{27}$ Second, it was unclear whether the more generous approach to judgments from other Canadian provinces should also apply to the recognition and enforcement of foreign judgments from outside Canada. ${ }^{28}$ Third, it was unclear whether the private international law rules were constitutionalized, given that it was unnecessary for the court to determine that issue in order to reach its decision on the case.

For the purposes of this article, however, what is central is the nature of the influential policy arguments about the international

${ }^{23}$ J. McEvoy, "Federalism, Territorialism and Justice La Forest," in Johnson and McEvoy, supra note 6 at 345 .

${ }^{24}$ Morguard, supra note 1 at 1099 . Constitution Act, 1867 (U.K.), $3^{\circ} \& 3_{1}^{1}$ Vict., c. 3, reprinted in R.S.C. 1985 , App. II, No. 5 .

${ }^{25}$ Scholars of Canadian constitutional law and conflict of laws had been speculating on this possibility in the years preceeding Morguard. In particular, see J Swan, "The Canadian Constitution, Federalism and the Conflict of Laws" (1985) $6_{3}$ Can. Bar Rev. 271 and V. Black, "Enforcement of Judgments and the Conflict of Laws" (1989) 9 Oxford J. Leg. Studies 547 , cited by the court in Morguard, supra note 1 at 1094 .

${ }^{26}$ Article IV. 1 of the US constitution provides that "[f]ull faith and Credit shall be given in each State to the public Acts, Records and Judicial Proceedings of every other State.'

27 See Blom, supra note 13.

${ }^{28}$ Lower courts have subsequently applied Morguard with respect to non-Canadian judgments; see J. Blom, "The Enforcement of Foreign Judgments: Morguard Goes Forth into the World" (1997) 28 Can. Bus. L. J. 373. 
that were expressed in Morguard - policy arguments whose influence I will track in the succeeding judgments.

AMCHEM PRODUCTS INC. V. BRITISH COLUMBIA

(WORKERS' COMPENSATION BOARD) $)^{29}$

The decision of the Supreme Court of Canada in Amchem is a crucial decision in a relatively discrete area of conflict of laws, namely the standards for issuance of anti-suit injunctions. In addition, the judgment has implications for the subject of jurisdiction more generally. The case concerned asbestos litigation in which a number of plaintiffs, most of whom were resident in British Columbia at the time of injury, brought suit in the state of Texas against a number of corporate defendants. The plaintiffs included the Workers' Compensation Board of British Columbia, which had subrogated interests by virtue of having paid disability or death benefits to workers whose health had allegedly been adversely affected by asbestos. On a motion by the defendants, the British Columbia Supreme Court in chambers issued an anti-suit injunction restraining the plaintiffs from continuing the US tort litigation.

In contrast to Morguard, the Supreme Court of Canada was dealing with an international dispute rather than a federal dispute. Moreover, Texas has been one of the most aggressive jurisdictions in the United States in assuming jurisdiction and has become a forum of choice for plaintiffs from all over North America and the world. The British Columbia courts and the Supreme Court of Canada, then, were wrestling with a jurisdiction that was perceived to be one of the most assertive in the world.

The history of asbestos litigation, of which this case was a part, made the outcome in Amchem that much more striking. Through the 1980 s and 1990 s, the proceedings on the tort claims had been dominated by complicated procedural strategies. Indeed, the procedural complexity of the litigation has generated a number of leading rulings on civil procedure and litigation practice, including two of the core decisions of the tetralogy. ${ }^{30}$ The procedural

${ }^{29}$ Amchem, supra note 1. For commentary, see E. Edinger, "Conflict of Laws - Discretionary Principles - Forum Non Conveniens - Anti-Suit Injunctions: Amchem Products Inc. v. British Columbia (Workers Compensation Board)" (1993) 72 Can. Bar Rev. 366.

${ }^{30}$ In Canada, litigation and legislation related to asbestos has been the source of many leading decisions testing the limits of the rules of civil procedure, including the conflict of laws. The Supreme Court of Canada had heard only a few 
manoeuvring at times rivalled that of such famous jurisdictional battles between United States and Commonwealth judges as the Laker Airways v. Sabena litigation. ${ }^{31}$ In the background to the Amchem case were a series of injunctions by the British Columbia and the Texas courts that included anti-suit injunctions, anti-anti suit injunctions, and, arguably, an anti-anti-anti suit injunction. ${ }^{32}$

The issue directly before the court was the appropriate standard for the granting of an anti-suit injunction. The unanimous judgment of the five-member court, written by Justice John Sopinka but with Justice La Forest notable among the concurring members of the court, sets a very high standard for the granting of antisuit injunctions. The test to be used has two stages. First, a court should consider whether the foreign court "could reasonably have concluded that there was no alternative forum that was clearly more appropriate." ${ }^{33}$ In the second stage, a court should consider whether the injunction would "deprive the plaintiff of advantages in the foreign forum of which it would be unjust to deprive him." 34 Justice Sopinka noted that the result of these principles would be that no anti-suit injunction would be granted in situations where the "foreign court assumes jurisdiction on a basis that generally conforms to our rule of private international law relating to the forum non conveniens." 35

Among the identified policy reasons for this restrictive standard for granting anti-suit injunctions were concerns of comity. Justice Sopinka quoted the definition of comity from Justice La Forest's

years earlier an asbestos litigation case on the standard for dismissal of an action for failure to state a cause of action; Hunt v. Carey Canada Inc., [1990] 2 S.C.R. 959. Hunt, supra note 1 arose out of the same asbestos litigation. Asbestos even plays a role in Canadian litigiousness at the interstate level of the World Trade Organization [hereinafter WTO]; see, for example, European Communities Measures Affecting Asbestos and Asbestos-Containing Products, 18 September 2000, Doc. WT/DS135/R (Panel Report), 12 March 2001, Doc. WT/DS135/AB/R (Appellate Body Report), in which Canada unsuccessfully challenged French restrictions on the import of asbestos and asbestos products.

${ }^{31}$ Laker Airwaysv. Sabena, Belgian World Airlines, 731 F.2d 909 (1984). For a description of the Laker Airways litigation, see L. Collins, Essays in International Litigation and the Conflict of Laws (Oxford: Oxford University Press, 1994) at 1 10-16. The reaction of the US court in the Laker Airways litigation is mentioned in Amchem, supra note 1 at 913 .

32 Amchem, supra note 1 at $905-08$.

33 Ibid. at 932 .

34 Ibid., quoting from SNI Aérospatialev. Lee KuiJak, [1987] 1 A.C. 871 (H.L) [hereinafter Aérospatiale].

35 Ibid. at 934 . 
judgment in Morguard ${ }^{36}$ and observed that anti-suit injunctions are generally considered to be inconsistent with comity. Although antisuit injunctions are still needed because of the injustice that might be caused by courts of other jurisdictions inappropriately assuming jurisdiction, Justice Sopinka observed that Canadian courts should only entertain such applications where a "serious injustice will be occasioned as a result of the failure of a foreign court to decline jurisdiction." 37

In the course of its judgment, the court confirmed the use of the forum non conveniens doctrine in Canada. Under the test for forum non conveniens, a court should grant a stay of proceedings if "the existence of a more appropriate forum" is clearly established. ${ }^{38}$ The status of this doctrine had been unclear. An earlier Supreme Court of Canada case had signalled that it might be applicable in Canada, and many lower courts and academic commentators had supported it. ${ }^{39}$ In Amchem, the Supreme Court of Canada approved of the use of the doctrine both in situations of service ex juris and in applications for a stay of proceedings. In its judgment, the court cited two House of Lords decisions of Lord Goff, Spiliada Maritime Corp. v. Cansulex Ltd. and SNI Aérospatialev. Lee Kui Jak, which reformed the English rules with respect to forum non conveniens and to anti-suit injunctions ${ }^{40}$ In citing the House of Lords and Privy Council decisions so closely, as well as in its detailed survey of the English, United States, and Australian laws on anti-suit injunctions, the Supreme Court of Canada evidenced its comfort with continuing the well-established Canadian practice of judicial borrowing from foreign courts. ${ }^{41}$

The judgments in this case are less notable than the combination of the doctrines and the application in this particular case. The House of Lords decision in Spiliada and the Privy Council decision in Aérospatiale changed the English tests, but, in their application to the facts, the House of Lords signalled a much less deferential attitude. Ironically, the House of Lords in Spiliada refused to

${ }^{36}$ Ibid. at $9^{1} 4^{-1} 5$.

37 Ibid. at 915 .

38 Ibid. at 921.

${ }^{39}$ Antares Shipping Corp. v. The Ship "Capricorn," [1977] 2 S.C.R. 422.

${ }^{40}$ Spiliada Maritime Corp. v. Cansulex Ltd., [1987] 1 A.C. 46o (H.L.) [hereinafter Spiliada]; Aérospatiale, supra note 34 .

${ }^{41}$ See G.V. La Forest, "The Use of International and Foreign Material in the Supreme Court of Canada," in Proceedings of the 1988 Conference of the Canadian Council of International Law (Ottawa: Canadian Council on International Law, 1988) 230. 
grant a stay of proceedings in England on forum non conveniens grounds in which British Columbia was the other jurisdiction with strong connections to the litigation. ${ }^{42}$ Moreover, in Aérospatiale, the Privy Council held that an anti-suit injunction should be granted against a Texas court, which was the same jurisdiction that was involved in the Amchem case.

In the Amchem case, the Supreme Court of Canada was dealing with the courts of Texas, but, unlike the Privy Council in Aérospatiale, it applied the highly deferential standard it set out as the rule. The Supreme Court of Canada did so even though the Texas courts did not have at the time a doctrine of forum non conveniens, ${ }^{43}$ a fact that seemed significant to the granting of the anti-suit injunction by both the trial court and the British Columbia Court of Appeal. ${ }^{44}$ The trial court also seemed troubled by the anti-anti suit injunction that had been granted by the Texas court. In contrast, the Supreme Court of Canada, acting in a magnanimous fashion, focused on the issue of whether the Texas court had, on the particular facts at stake, acted in an unjust way. It concluded that while Texas did not have a forum non conveniens doctrine, it was not a clearly inappropriate forum in this case. There was enough of a connection that the court, while it may not have agreed that Texas was the best forum for the trial of these claims, gave the Texas court significant deference and refused to grant the anti-suit injunction.

Amchem carried the logic of the Morguard decision into the area of jurisdiction. By approving a lower standard for forum non conveniens and a high standard for anti-suit injunctions, the judgment set Canadian courts on a path wherein the assumption of jurisdiction was to be much more deferential towards foreign courts. Moreover, the Amchem decision suggested that the new generous, cooperative attitude of Canadian courts, which was developed in the Morguard decision, would apply vis-à-vis non-Canadian courts, including courts from even the most aggressive foreign jurisdictions. ${ }^{45}$

42 See Spiliada, supra note 40 at $485^{-88}$.

${ }^{43}$ See L. Silberman, "Developments in Jurisdiction and Forum Non Conveniens in International Litigation: Thoughts on Reform and a Proposal for a Uniform Standard" (1 993) 28 Tex. Int'l L. J. 5ol.

${ }^{44}$ See the discussion of the lower court judgments, Amchem, supra note 1 at $910-11$.

45 The willingness of the Canadian courts to accept forum non conveniens and to restrict anti-suit injunctions without seeking reciprocity generated favourable, if surprised, commentary in the United States; see, for example, A. Lowenfeld, "Forum Shopping, Antisuit Injunctions, Negative Declarations, and Related Tools of International Litigation" (1997) $9^{1}$ Am. J. Int'l L. $3^{1} 4$ at 323-24. 
HUNT V. T E N $N L C^{46}$

In Hunt, the Supreme Court of Canada addressed the procedural barriers to the conduct of cross-border civil litigation placed by a blocking statute. Provisions of the Quebec Business Concerns Records Act $^{47}$ prohibited the removal of documents from Québec for purposes of discovery in asbestos litigation proceedings in British Columbia. The case therefore concerned a procedural statute that could act as an effective barrier to litigation in a forum that had valid connections to the suit as well as being the forum chosen by the plaintiff. The British Columbia courts, on motions of the plaintiff for orders of discovery against the Québec defendants, ruled that the blocking statute of the sister province had to be respected. In order to avoid putting the defendants in an untenable position, no discovery order would be made by the British Columbia court.

In the Supreme Court of Canada, the majority concluded that the Quebec Business Concerns Records Act was constitutionally inapplicable with respect to litigation in another Canadian province. It left unclear whether these constitutional limits would also apply with respect to litigation in a non-Canadian jurisdiction. The judgment of the court, again written by Justice La Forest, observed that the clear purpose of the blocking statute was a decision by a provincial legislature to prevent the successful litigation of claims against asbestos companies in foreign jurisdictions, particularly suits in US courts. The fact that the legislature had a clear public purpose did not seem to argue for deference on the part of the court. Rather, the court focused on how this purpose was clearly problematic for international and federal comity:

The whole purpose of a blocking statute is to impede successful litigation or prosecution in other jurisdictions by refusing recognition and compliance with orders issued there. Everybody realizes that the whole point of blocking statutes is not to keep documents in the province, but rather to prevent compliance, and so the success of litigation outside the province that that province finds objectionable. This is no doubt part of sovereign

${ }^{46}$ Hunt, supra note 1. For commentary, see V. Black and W. MacKay, "Constitutional Alchemy in the Supreme Court: Hunt v. T\& Nplc" (1994) 5 N.J.C.L. 79; C. Walsh, "Conflict of Laws - Enforcement of Extra Provincial Judgments and In Personam Jurisdiction of Canadian Courts: Hunt v. T $\mathcal{F}^{2} N$ plc" (1994) 73 Can. Bar Rev. 394; Edinger, supra note 5; R. Wisner, "Uniformity, Diversity and Provincial Extraterritoriality" (1995) 4o McGill L. J. 759.

${ }^{47}$ Quebec Business Concerns Records Act, R.S.Q., c. D-12. 
right, but it certainly runs counter to comity. In the political realm it leads to strict retaliatory laws and power struggles. And it discourages international commerce and efficient allocation and conduct of litigation. It has similar effects on the interprovincial level, effects that offend against the basic structure of the Canadian federation. ${ }^{48}$

The blocking statute ran counter to the values of comity, order, and fairness that had been central to the judgments in Morguard and Amchem and that had justified reform of the relevant common law rules. In this appeal, however, statutory provisions passed by a legislature were at stake rather than common law rules. The court's decision, therefore, rested on Canadian constitutional provisions of the federal division of powers, including the interpretation of provincial powers under section 92, in particular, section 92 (13), which concerns "property and civil rights in the Province." Beyond a "pith and substance" analysis of section 92(13), Justice La Forest further invoked the diverse set of constitutional provisions that he had identified in Morguard and that, for him, provided the basic structure of the Canadian federation and demonstrated the "obvious intention of the Constitution to create a single country." 49 These diverse constitutional provisions included common citizenship, inter-provincial mobility (reflected in section 6 of the Charter), the Canadian common market (reflected in sections 91 (2), 91 (10), 121 and the peace, order, and good government clause), and the "unitary structure of the Canadian judicial system with the Supreme Court of Canada at its apex."50

Justice La Forest emphasized, seemingly more than any specific provision of the constitution, how the use of blocking statutes ran counter to the basic policies of economic efficiency and equality of treatment in a federal state:

It is inconceivable that in devising a scheme of union comprising a common market stretching from sea to sea, the Fathers of Confederation would have contemplated a situation where citizens would be effectively deprived of access to the ordinary courts in their jurisdiction in respect of transactions flowing from the existence of that common market. The resultant higher transactional costs for interprovincial transactions constitute an infringement on the unity and efficiency of the Canadian marketplace ... as well as unfairness to the citizen. ${ }^{51}$

\footnotetext{
4* Hunt, supra note 1 at 327 .

49 Morguard, supra note 1 at 1099 , cited in Hunt, supra note 1 at 322.

50 Hunt, supra note 1 at 322 .

51 Ibid. at 330.
} 
For the court, the lack of order and fairness of provincial blocking statutes was highlighted by the fact that the basic rules of civil procedure were the same in the different provinces of Canada. Discovery would be available to a plaintiff if he or she brought an action in Québec or if both parties to the action had been from British Columbia, "[b]ut somehow, because of the fortuitous combination of litigation in British Columbia involving a defendant from Quebec or Ontario, the discovery process is barred." ${ }^{2}$

\section{TOLOFSON V. JENSEN; LUGAS (LITIGATION GUARDIAN OF) V. GAGNON ${ }^{53}$}

The Supreme Court of Canada's judgment in Tolofson completed the tetralogy by instituting reform in the area of choice of law. In turning to choice of law, the court addressed perhaps the most vexed area in conflict of laws: choice of law in tort. Choice of law in tort poses special difficulties partly because in contrast to crossborder contractual situations there is usually no opportunity for parties to indicate clearly that their legal relation is connected to the governing law of a particular jurisdiction. ${ }^{54}$ Yet, choice of law rules in tort are important in private international relations because of the numerous situations where non-contractually related parties with connections to different jurisdictions will find themselves involved in a tort dispute. Moreover, international tort litigation is frequently large in scale and complex in its international connections. Environmental accidents and defective products, for example, can cause damage that spreads across many jurisdictional borders, especially given contemporary technology and the scope of the international market. Finally, tort law is the subject of private law that is most closely associated with broader public policy purposes, including deterrence and punishment. ${ }^{55}$

52 Ibid. at 331 .

${ }^{53}$ Tolofson, supra note 1. For commentary, see J.-G. Castel, "Back to the Future! Is the New 'Rigid' Choice of Law Rule for Interprovincial Torts Constitutionally Mandated?" (1995) 33 Osgoode Hall L. J. 35; P. Kincaid, "Jensen v. Tolofson and the Revolution in Tort Choice of Law" (1995) 74 Can. Bar Rev. 537.

54 The tort/contract distinction can be overstated. Many disputes involve overlapping claims in contract and tort. Moreover, some tort claims involve situations with a transactional character where there are possibilities of bilateral bargaining and negotiation; see, for example, M. Whincop and M. Keyes, "The Market Tort in Private International Law" (1999) 19 Northwestern J. Int'l L. and Bus. 215 .

${ }^{55}$ It is therefore not surprising that choice of law in tort was central to the development of the "governmental-interest analysis" approach in the United States; see, 
In the United Kingdom and in many Commonwealth jurisdictions, a restrictive "double actionability" rule had prevailed with respect to choice of law in tort. The rule required that the accident be actionable under the rules of both the forum state (lex fora) and the state where the accident occurred (lex loci delicti). The result was a two-pronged rule that effectively erected two barriers to recovery by plaintiffs. It was widely believed that this rule had to be reformed. In the judgment in Tolofson, Justice La Forest clearly signalled his dislike for the old rules:

What strikes me about the Anglo-Canadian choice of law rules as developed over the past century is that they appear to have been applied with insufficient reference to the underlying reality in which they operate and to general principles that should apply in responding to that reality. Often the rules are mechanistically applied. At other times, they seem to be based on the expectations of the parties, a somewhat fictional concept, or a sense of "fairness" about the specific case, a reaction that is not subjected to analysis, but which seems to be born of disapproval of the rule adopted by a particular jurisdiction. The truth is that a system of law built on what a particular court considers to be the expectations of the parties or what it thinks is fair, without engaging in further probing about what it means by this, does not bear the hallmarks of a rational system of law. ${ }^{56}$

What is notable about the majority judgment that follows is not that the court chose reform but rather its choice of reform that was extreme in its simplicity. Following a decision of the Australian High Court,${ }^{57}$ the Supreme Court of Canada radically moved from the double actionability rule to a rigid lex loci delicti rule. The return to the rule for choice of law in tort that had applied in the early twentieth century was a surprising turn to many scholars of Canadian conflict of laws. ${ }^{58} \mathrm{~A}$ number of less rigid alternatives to the lex

for example, Babcock v. Jackson, i 2 N.Y. 2d 473 (1963); B. Currie, Selected Essays on the Conflict of Laws (Durham, NC: Duke University Press, 1963); L. Brilmayer, Conflict of Laws, and ed. (Boston: Little, Brown, 1995) c. 2.

56 Tolofson, supra note 1 at 104 6-47. For commentary, see, for example, N. Guthrie, "'A Good Place to Shop': Choice of Forum and the Conflict of Laws" (1995) 27 Ottawa L. Rev. 201.

57 In particular, the minority concurring opinion of Chief Justice Mason in Breavington v. Godleman, (1988), 8o A.L.R. 362 (Australia H.C.). The ratio of this case is almost unascertainable given the multiple judgments pulling in various directions. It is interesting that an equally muddy decision is also a leading case in English choice of law in tort; Boys v. Chaplin, [1971] A.C. 356 (H.L.). For a discussion of this case and its background in English choice of law in tort, see J. Morris, The Conflict of Laws, $4^{\text {th }}$ ed. by J.D. McClean (London: Sweet and Maxwell, 1993) at 280-91.

58 See, for example, Castel, supra note 53. 
loci delicti rule existed. The idea of the "proper law of the tort," for example, as developed by John Morris, attempted to avoid rigidity and arbitrariness by assessing the various connecting factors of the tort to the different jurisdictions. ${ }^{59}$ British legislation, which is based on proposals of the English and Scottish Law Commissions, implements rules based on a "place of the accident plus" formulation, which chooses the law of the place of the tort, but with a number of limited exceptions..$^{60}$

The court's reasons for choosing the rigid rule evidences the priority of certain policy values for contemporary private international law, most of which had already been articulated in earlier cases of the court. Justice La Forest evoked the reforms in Morguard and Hunt for the idea that, with respect to rules of recognition and enforcement and jurisdiction of courts in transactions with ties to more than a single state, a plaintiff should generally be able to choose the jurisdiction most convenient to it, because such choice "fosters mobility and a world economy." ${ }^{11}$ However, Justice La Forest also noted that courts have developed rules to restrict "overreaching," such as the "real and substantial connection" test with respect to recognition and enforcement of judgments and forum non conveniens analysis for refusal to exercise jurisdiction. ${ }^{62}$

What choice of law rule in tort is consistent with the view of the international system that was developed in Morguard, Amchem, and Hunt? Justice La Forest reasoned that

[f] rom the general principle that a state has exclusive jurisdiction within its own territory and that other states must under principles of comity respect the exercise of its jurisdiction within its own territory, it seems axiomatic to me that, at least as a general rule, the law to be applied in torts is the law of the place where the activity occurred, i.e., the lex loci delicti. ${ }^{63}$

The majority judgment of Justice La Forest cites a number of "practical considerations" for the choice of the lex loci delicti rule. First, he argues that the rule "has the advantage of certainty, ease of application and predictability." ${ }^{4}$ Second, he argues that the territorial

59 J. Morris, "The Proper Law of A Tort" (1951) 64 Harv. L. Rev. 881.

${ }^{60}$ Part III of the Private International Law (Miscellaneous Provisions) Act (U.K.) 1995. For a discussion of the Law Commission work that informed the new laws, see P. North, Essays in Private International Law (Oxford: Clarendon Press, 1993), c. 4 .

61 Tolofson, supra note 1 at 1049 .

62 Ibid.

${ }^{63}$ Ibid. at $1049^{-5}{ }^{\circ}$.

${ }^{64} \mathrm{Ibid}$ at 1050. 
rule accords with normal expectations of people. Third, he invokes the idea of international order in a world where no rule exists to single out the appropriate jurisdiction:

If other states routinely applied their laws to activities taking place elsewhere, confusion would be the result. In our modern world of easy travel and with the emergence of a global economic order, chaotic situations would often result if the principle of territorial jurisdiction were not, at least generally, respected. Stability of transactions and well grounded legal expectations must be respected. Many activities within one state necessarily have impact in another, but a multiplicity of competing exercises of state power in respect of such activities must be avoided. ${ }^{65}$

Although the lex loci delicti rule would ensure that Canadian courts encouraged an orderly choice of law, the rule is controversial where many or all of the parties' connections, other than to their physical location at the time of the accident, are to jurisdictions other than the place of the accident and where the laws of the other relevant jurisdictions would lead to very different outcomes. This was the situation in the Tolofson case itself, in which the plaintiff infant passenger and the defendant driver (and, in the background, the driver's insurer) were both from British Columbia. Under the laws of Saskatchewan, which was the place of the accident, the plaintiff's claim would have been defeated by a guest passenger statute and a limitations period provision on suits by minors, while the same claim could have succeeded under the laws of British Columbia. In the face of such arguments, Justice La Forest maintained the importance of the lex loci delicti rule:

I remain unconvinced by these arguments. These "public policy" arguments simply mean that the court does not approve of the law that the legislature having power to enact it within its territory has chosen to adopt. These laws are usually enacted on the basis of what are often perceived by those who make them as reasonable, though they may turn out to be unwise. The residents of the jurisdiction must put up with them until they are modified, and one does not ordinarily ignore the law of the land in favour of those who visit. True, it may be unfortunate for a plaintiff that he or she was a victim of a tort in one jurisdiction rather than another and so be unable to claim as much compensation as if it had occurred in another jurisdiction. But such differences are a concomitant of the territoriality principle. While, no doubt, as was observed in Morguard, the underlying principles of private international law are order and fairness, order comes first. Order is a precondition to justice. ${ }^{66}$

\footnotetext{
65 Ibid. at 1051 .

${ }^{66}$ Ibid. at $105^{8}$.
} 
The majority invoked the idea of convergence in the underlying laws of different jurisdictions as a reason why the emphasis on order and certainty would not constitute significant injustice or defeated expectations:

I should add that the "public policy" problems, particularly between the provinces, tend to disappear over time. Ever since the launching of the Tolofson case, Saskatchewan has repealed its guest passenger statute and has changed the rule regarding the limitation period of minors. The biggest difference between provinces now is in insurance schemes, and this only creates problems of quantum, not of liability. ${ }^{67}$

Although such concerns would offer little comfort to the plaintiffs in the particular case, it seems that Justice La Forest and the court were focused on the broader issues of international and federal public policy.

\section{Part 3: The Internationalization of Canadian Private International LaW: Two Contrasting Modes}

The tetralogy has much to say about the need for the internationalist reform of traditional rules, and one way to understand the tetralogy is to view it as part of a process of the "internationalization" of Canadian private international law through the mechanisms of public international law. I will argue in the proceeding text that values that are important in public international law have much to do with the kinds of reforms and policy justifications made in the tetralogy. However, these values play an indirect role. What the tetralogy is not is the traditional use of public international law processes - whether customary or conventional international law - to reform private international law. Instead, in Canada, as in most non-European jurisdictions, private international law remains largely municipal in its sources and venues. What the tetralogy does involve is the triumph of a substantive vision and a set of policy objectives that are identifiably associated with the goals of public international law.

\section{INTERNATIONALIZATION THROUGH INTERNATIONAL AGREEMENTS}

International conventions have not traditionally been significant sources of the rules of private international law in common law jurisdictions, and the Supreme Court of Canada in the tetralogy does not institute legal reform of specific rules because the court

${ }^{67}$ Ibid. at 1059 . 
believed reforms were necessitated by binding international treaty commitments on the part of Canada. However, the decisions of the court do draw on, parallel, and augment some limited reforms instituted through the implementation of international conventions on related subjects.

Like most other common law jurisdictions, Canada has signed few of the conventions developed through the Hague Conference on Private International Law (Hague Conference). ${ }^{68}$ The Hague conventions to which Canada is a party, such as the Convention on Service Abroad of Judicial and Extrajudicial Documents in Civil and Commercial Matters and the Convention on the Taking of Evidence Abroad in Civil and Commercial Matters, ${ }^{69}$ concern matters of minor practical importance compared with the reforms instituted through the tetralogy. However, they can be viewed as precursors in their approach to facilitating mutually beneficial objectives through the use of cooperation among courts and diplomatic offices. ${ }^{70}$

International treaties and institutions have had their greatest impact in Canadian private international law with respect to arbitration. In 1986, Canada signed the Convention on the Recognition and Enforcement of Foreign Arbitral Awards (New York Convention), which both eased procedures for, and limited grounds for refusal of, the recognition and enforcement of foreign arbitral awards. ${ }^{71}$ Federal and provincial legislation subsequently

${ }^{68}$ There are, in addition, the private international law provisions of specialized conventions such as the Convention for the Unification of Certain Rules Relating to International Carriage by Air, October 12, 1929,137 L.N.T.S. 13, Can. T.S. 1947 No. ${ }_{15}$, as amended by the Protocol to Amend the Convention for the Unification of Certain Rules Relating to International Carriage by Air, September $28,1955,478$ U.N.T.S. 371 , Can. T.S. 1964 , No. 29.

69 Convention on Service Abroad of Judicial and Extrajudicial Documents in Civil and Commercial Matters, November $15,196_{5}, 65^{8}$ U.N.T.S. ${ }_{16}$; Convention on the Taking of Evidence Abroad in Civil and Commercial Matters, March 18 , $197^{\circ}, 847$ U.N.T.S. 241 . See generally, G. Droz, "A Comment on the Role of the Hague Conference on Private International Law" (1994) 57 Law and Contemp. Probs. 3 .

${ }^{70}$ For a sense of this hopeful cosmopolitan and internationalist sentiment, see, for example, T.M.C. Asser Institute, The Influence of the Hague Conference on Private International Law: Selected Essays to Celebrate the Iooth Anniversary of the Hague Conference on Private International Law (Dordrecht: Martinus Nijhoff, 1993); Hague Conference on Private International Law, Proceedings of the Seventeenth Session, Tome 1 - Second Part, "Centenary” (La Haye: SDU Publishers, 1994-95).

${ }^{71}$ Convention on the Recognition and Enforcement of Foreign Arbitral Awards, June 10,1958 , 330 U.N.T.S. 38, Can. T.S. 1986 No. 43 [hereinafter New York Convention]. See J.-G. Castel et al., eds., The Canadian Law and Practice of 
implemented the New York Convention. ${ }^{72}$ Canadian jurisdictions have since implemented legislation based on the 1985 United Nations Commission on International Trade Law (UNCITRAL) Model Law on International Commercial Arbitration. ${ }^{73}$ The Canadian reforms were part of a broader international movement towards acceptance and promotion of international commercial arbitration ${ }^{74}$ The legislative acceptance of international commercial arbitration paralleled and, in important senses, anticipated the policy outlook that the Supreme Court of Canada adopted in the tetralogy.

The nature of the reforms in the Canadian law related to international commercial arbitration and the policy justifications for the reforms share many of the characteristics of the reforms and policy justifications in the tetralogy. The judicial acceptance of similar values is in some sense unsurprising. No arbitration system is self-executing. National courts are needed both to enforce arbitration clauses and to recognize and enforce arbitral awards. ${ }^{75}$ Although the Supreme Court of Canada has not issued a judgment concerning the New York Convention and the UNCITRAL Model Law, lower courts in Canada have been very supportive of the relevant legislation and the use of arbitration. For example, lower courts have generally supported the arbitration legislation by staying court proceedings and enforcing arbitration clauses, restricting court interference with arbitration procedures, and limiting the judicial review of arbitral awards made in Canadian jurisdictions and of foreign arbitral awards. ${ }^{76}$ This approach contrasts

International Trade with Particular Emphasis on Export and Import of Goods and Sertices, 2nd ed. (Toronto: Emond Montgomery, 1997) at 724-25.

${ }^{72}$ See J.B. Casey, International and Domestic Commercial Arbitration (Scarborough, ON: Carswell, 1992) (updated 1999), c. 2, for a review of the federal and provincial legislation.

${ }^{73}$ United Nations Commission on International Trade Law Model Law on International Commercial Arbitration, June 21, 1985, (1985) 24 I.L.M. 1302. For commentary on relevant Canadian law and practice, see Castel et al., supra note 71 at c. 21.

${ }^{74}$ Dezalay and Garth, supra note 9, provide a sophisticated sociological analysis of the establishment of international commercial arbitration in a number of different jurisdictions.

75 The failure to fully attend to the role of national courts is one of the principal weaknesses of the account by Dezalay and Garth, supra note 9, of the establishment of the arbitration regime.

${ }^{76}$ For example, see the review of the legislative provisions and judicial interpretation related to international commercial arbitration in R. Pepper, "Why 
with the greater suspicion that traditionally characterized the common law attitude towards international commercial arbitration. In Burlington Northern Railroad Co. v. Canadian National Railway Co., ${ }^{77}$ the Supreme Court of Canada, with Justice La Forest writing for the court, reinstated a trial decision enforcing an arbitration clause, adopting the reasons of a dissenting judge in the appellate court who adopted the view that it was

the very strong public policy of this jurisdiction that where parties have agreed by contract that they will have the arbitrators decide their claims, instead of resorting to Courts, the parties should be held to their contract. ${ }^{78}$

The fact that a similarly supportive stance towards international conventions and implementing legislation in private international law would probably have been adopted by the Supreme Court of Canada is demonstrated by its approach to the Convention on the Civil Aspects of International Child Abduction (Child Abduction Convention) ${ }^{79}$ In Thomson v. Thomson, ${ }^{80}$ a majority of the court interpreted the laws of Manitoba that implemented the Child Abduction Convention and held that a court deciding on the return of a child should not simply consider the best interests of the particular child as it would in a domestic custody hearing. ${ }^{81}$ The majority also indicated that it would consider that an application for the return of a child under the convention would pre-empt a local custody application — in this case, a transitory order giving

Arbitrate?: Ontario's Recent Experience with Commercial Arbitration" (1998) 36 Osgoode Hall L. J. 807; Castel et al., supra note 71 at c. 21 ; Quintette Coal Ltd. v. Nippon Steel Corp., [1991] 1 W.W.R. 219 (B.C.C.A.), leave to appeal to S.C.C. refused [1 990] 2 S.C.R. x.

7 Burlington Northern Railroad Co. v. Canadian National Railway Co., [1997] 1 S.C.R. 5 .

${ }^{78}$ Burlington Northern Railroad Co. v. Canadian National Railway (1995), 7 B.C.L.R. (3d) 80 at 94 (B.C.C.A.), quoting from Boart Weden $A B$ v. NYA Stomnes $A B$ (1988), 41 B.L.R. 295 at $302-03$ (Ont. H.C.).

${ }^{79}$ Convention on the Civil Aspects of International Child Abduction, October 25, 1980 , Can. T.S. 1983 No. 35 . This convention was also considered in W. V.) v. S.(D.), [1 1996] 2 S.C.R. 108; and briefly in Gordon v. Goertz, [1 996] 2 S.C.R. 27 at 76-77, L'Heureux-Dubé J.

80 Thomson v. Thomson, [1994] 3 S.C.R. 551 at $578-80$, La Forest J. [hereinafter Thomson]. For commentary, see V. Black and C. Jones, Case Comment (1994) 12 C.F.L.Q. 321 .

${ }^{81}$ Justices Claire L'Heureux-Dubé and Beverley McLachlin dissented on this point. 
the mother interim custody while she proceeded with a custody application in Scotland. Rather, the court used its remedial flexibility to advance the "purpose and spirit" of the Child Abduction Convention by ordering the return of the child to Scotland from Canada under an undertaking from the Scottish father to commence custody proceedings expeditiously before a Scottish court and not to take physical custody of the child until a Scottish court permitted such custody. ${ }^{82}$

The New York Convention, the UNCITRAL Model Law on International Commercial Arbitration, and other important conventions on private international law that have been reached among various European jurisdictions, ${ }^{83}$ as well as the Hague conventions, suggest to some commentators that private international law is shifting from development and reform focused on state courts to reform negotiated through international conventions and implemented through state legislation. The most recent effort for the internationalization of private international law through international conventions is the negotiation under the auspices of the Hague Conference to reach a multilateral convention on recognition and enforcement of judgments. ${ }^{84}$ Unlike the earlier Hague conventions, this treaty would cover a core topic of private international law. However, a number of barriers exist to the successful completion of such a convention..$^{85}$ Furthermore, it is quite likely

82 Thomson, supra note 80 at 605 , La Forest $\mathrm{J}$.

8s Convention on Jurisdiction and the Enforcement of Judgments in Civil and Commercial Matters, September 27, 1968, 1262 U.N.T.S. 1653 [hereinafter Brussels Convention]; Convention on Jurisdiction and the Enforcement of Judgments in Civil and Commercial Matters, September $16,1988,1659$ U.N.T.S. 13 [hereinafter Lugano Convention]; Convention on the Law Applicable to Contractual Obligations, June 19, 1980,1605 U.N.T.S. 59 [hereinafter Rome Convention].

${ }^{84}$ For a useful discussion of the Hague Conference on Private International Law negotiations concerning a treaty for recognition and enforcement of judgments, see "Symposium Enforcing Judgments Abroad: The Global Challenge" (1998) 24 Brooklyn J. Int'l L. 1; A. von Mehren, "Recognition and Enforcement of Foreign Judgments: A New Approach For the Hague Conference?" (1994) 57 Law and Contemp. Probs. 271.

${ }^{85}$ V. Black, "Commodifying Justice for Global Free Trade: The Proposed Hague Judgments Convention" (2000) 38 Osgoode Hall L. J. 267. The Preliminary Draft Convention on Jurisdiction and Foreign Judgments in Civil and Commercial Matters was adopted by the Special Commission of the Hague Conference on October 30, 1999; text can be found online at <http://www.hcch.net/e/ conventions/draft36e.html > (last modified: October zo, 1999). 
that any such convention will include substantial room for variation with respect to municipal rules among different signatories. ${ }^{86}$

In addition to the practical difficulties of negotiating new international conventions, some further limits on the use of public international law as a mode for reform in private international law are demonstrated by the somewhat undisciplined use of international law materials by the Supreme Court of Canada in the tetralogy. The court's judgments frequently refer to international and comparative materials. For example, Justice La Forest's judgment in Morguard contrasted Canadian rules on recognition and enforcement with developments under the European conventions on recognition and enforcement of judgments. ${ }^{87}$ One reading might be that the Canadian courts are engaged in a process of harmonization through dialogue with foreign and international legal systems $^{88}$ and incorporation of international law norms into Canadian law. However, as Stephen Toope has observed, the court has not developed a clear understanding of its use of either international conventions or customary international law. ${ }^{89}$ At the same time, the court repeatedly invokes international materials as useful supports for interpreting and developing Canadian law. Such engagement with international materials permits some harmonization of rules, where the court feels inclined in that direction, but not where it disagrees with, or is uninformed about, customary or conventional international law. A lack of clarity with respect to the use of customary and conventional international law may partly be related to an effort by Canadian courts to bracket contentious issues of federalism, such as the status of the treaty implementation power, which is an issue to which I will return later in this article. For the

${ }^{86}$ R. Weintraub, "How Substantial Is Our Need for a Judgments-Recognition Convention and What Should We Bargain Away to Get It?" (1998) 24 Brooklyn J. Int'l L. 167.

${ }^{87}$ Morguard, supra note $\mathrm{I}$ at 1098 and 1100 .

${ }^{88}$ See, for example, A. Bayefsky, International Human Rights Law: Use in Canadian Charter of Rights and Freedoms Litigation (Toronto: Butterworths, 1992); A.-M. Slaughter, "A Typology of Transjudicial Communication" (1994) 29 U. Richmond L. Rev. 99. The judges of the court frequently discuss this subject in speeches and articles; for example, La Forest, supra note 41 ; G.V. La Forest, "The Expanding Role of the Supreme Court of Canada in International Law Issues" (1996) 34 Can. Y.B. Int'1 L. 89 at 97-100. Given the limited range of "appropriate" topics for judicial speeches, the prominence of this subject is suggestive of the consensus behind internationalism in Canada.

89 S. Toope, "Canada and International Law," in The Impact of International Law on the Practice of Law in Canada (The Hague: Kluwer, 1999) 33 at $34-38$. 
purposes of this section, however, the undisciplined approach of Canadian courts to the use of international law sources supports the view that internationalization in private international law has not been primarily a matter of formally binding international law but, instead, more a matter of courts accepting and promoting internationalist policy values. This is reform through the mode of internationalist "consciousness."

\section{INTERNATIONALIZATION BY INTERNATIONALIST "CONSCIOUSNESS"}

The tetralogy evidences another, arguably more important, mode of internationalization of Canadian private international law an internationalization of the "consciousness" of Canadian legal decision-makers at the level of overall approach and policy orientation. ${ }^{90}$ Law operates as a link between norms and material consequences in various state apparatuses. In this sense, the tetralogy demonstrates the importance of "internationalism" as a set of beliefs that can have material effects both at the international level and at the municipal level. The judgments in the tetralogy repeatedly refer to the need to update traditional rules to meet the demands of contemporary international society. ${ }^{91}$

I believe that the tetralogy evidences a particular set of policy goals associated with internationalism. The facilitation of international commerce, the emphasis on comity and cooperation among state systems and courts, and the invocations against parochialism echo economic, political, and moral arguments familiar from other kinds of policy discourses concerning international relations and international society. In particular, I argue that significant characteristics of the policy vision found in the tetralogy track the economic, political, and moral aspirations of traditions of liberal internationalism. Focusing on the policy discussion in these four judgments offers an unusually salient opportunity to explore the different policy planks of liberal internationalist policy argumentation in law.

Even if the trend towards formal internationalization continues, I believe that a focus on internationalist policy consciousness in

${ }^{90}$ For a related analysis, see $\mathrm{H}$. Arthurs, "Globalization of the Mind: Canadian Elites and the Restructuring of Legal Fields" (1998) 12 Can. J. Law and Soc. 219.

${ }_{91}$ This trope of reform is a constant in international law; see D. Kennedy, "A New World Order: Yesterday, Today and Tomorrow" (1994) 4 Transnat'l L. and Contemp. Probs. 329. 
private international law is useful. This utility is partially due to the fact that the courts will continue to play a large role in addressing the many legal issues not subject to international conventions or national legislation. ${ }^{92}$ In addition, the interpretation of treaties and legislation and the application of provisions to particular disputes is often not a mechanical exercise but rather a creative process that involves courts inevitably in policy analysis. Moreover, the legislators, negotiators, academics, and policymakers who formulate, negotiate, and implement international conventions in this area share many of the same conceptions of the international that were articulated by the court in the tetralogy. A critical assessment of these policy justifications should therefore be useful to legal actors involved in the internationalization trend, regardless of whether law reform in private international law remains in the hands of municipal courts or becomes the subject of international agreements.

\section{Intellectual Contexts}

Since law is both a material and ideational social phenomenon, the role of general ideas, outlooks, and sentiments in generating particular legal regimes is obvious. Precise connections are very difficult to track. One approach is to look towards a shared legal "consciousness" of a particular group or society at a particular time.$^{93}$ Something like a common "vision" or "sentiment" concerning the international system can be shared by a number of different legal actors in a legal system, including judges, diplomats, bureaucrats, legislators, practitioners, and business actors.

Other accounts utilize the idea of legal "cultures" to illuminate the importance of background norms and beliefs in international law. ${ }^{94}$

92 The current situation in Britain is a good example of the continuing relevance of both traditions - international and municipal. One instance of the tensions generated by efforts to incorporate international conventions into a traditional common law subject are recent editions of the leading UK treatise; L. Collins, ed., Dicey $\mathcal{G}^{2}$ Morris on the Conflict of Laws, 12 th ed. (London: Sweet and Maxwell, 1993) [hereinafter Dicey $\mathcal{E}$ ' Morris]. On this tension, see R. Wai, "Book Review of Dicey $\mathcal{E}$ 'Morris on the Conflict of Laws, edited by L. Collins" (1997) 8 Eur. J. Int'1 L. 386 .

93 See, for example, D. Kennedy, "Toward an Historical Understanding of Legal Consciousness: The Case of Classical Legal Thought in America, $185^{\circ-1940 "}$ (1980) 3 Research in Law and Society.

${ }_{94}$ See, for example, O. Korhonen, International Law Situated: An Analysis of the Lawyer's Stance towards Culture, History and Community (The Hague: Kluwer, 200o), c. 2. 
Some of this scholarship has emphasized that to understand why arguments about internationalist reform have such a ready audience one must have an understanding of the international law elite as sharing a disciplinary "culture," which disposes them towards a fundamental, basic commitment to "the simple idea that things go better when they go internationally." national law, for example, has turned towards the biographical and professional class characteristics of legal decision-makers in order to illuminate some overlooked aspects of the discipline. ${ }^{96}$ This approach to international law seems appropriate because so many of its leading figures have similar backgrounds and similar values. Indeed, public international lawyers have been famously described by Oscar Schachter as an "invisible college" whose members share certain subject interests and outlooks. ${ }^{97}$

Other scholarship traces the connections of the belief systems of international lawyers to the more general intellectual and cultural currents of their time..$^{98}$ An illustrative study that explores the ideas of disciplinary and broader cultures of internationalism is the

${ }_{95}$ D. Kennedy, "The Disciplines of International Law and Policy" ( 1999) 12 Leiden J. Int'l L. 9 at 23.

${ }_{96}$ See, for example, "The Academic as Cosmopolite: Legal Visions of International Governance in the Twentieth Century," in On Violence, Money, Power and Culture: Reviewing the Internationalist Legacy: Proceedings of the $93^{\text {rd }}$ Annual Meeting (Washington DC: American Society of International Law, 2000), 325-31. In previous work, I attempted to provide some focus for this important aspect of international law by tracking the influence of the policy vision of the international system in the work and background of Justice La Forest, the leading judge on international law matters at the Supreme Court of Canada; Wai, supra note 6. Justice La Forest was the leading figure in the tetralogy as well. He wrote the majority judgment in three of the cases and was on the panel of five that decided the fourth. In the Amchem case, Justice Sopinka identifies his judgment as being consistent with the judgment and approach in Morguard; and in the later Hunt and Tolofson judgments, Justice La Forest in turn interprets the judgment in Amchem to be consistent with, and indeed an integrated component of, his vision for private international law in Canada.

97 O. Schachter, "The Invisible College of International Lawyers" (1977) 72 Northwestern U. L. Rev. 217.

${ }^{98}$ Nathaniel Berman pioneered this approach in his studies of the connections between the international law of the inter-war period and concurrent ideas of modernism in culture and politics. See, for example, N. Berman, "Modernism, Nationalism, and the Rhetoric of Reconstruction" (1992) 4 Yale J. L. and Humanities $35^{1}$; N. Berman, "But the Alternative is Despair": European Nationalism and the Modernist Renewal of International Law" (1993) 106 Harv. L. Rev. 1792. 
recent study of Sir Hersch Lauterpacht by Martti Koskenniemi..$^{99}$ Koskenniemi describes Lauterpacht's disciplinary efforts in international law as originating in a nineteenth-century "Victorian tradition," with "its liberal rationalism and its ideal of the rule of law, its belief in progress, its certainty about the sense and direction of history," 100 and coming "to rest in a pragmatism of the 1960 , a pragmatism which by now may have spent whatever creative force it once had." 101 Koskenniemi's study demonstrates how the biographical and national contexts of Lauterpacht's position as a Jew in Austria help to explain Lauterpacht's "assimilation" strategy of support for the Victorian tradition and for legal cosmopolitanism. ${ }^{102}$

In what follows, I try to elaborate on some of the disciplinary and national contexts for the internationalism of the Supreme Court of Canada's judgments in private international law. I will then focus on how the judgments rely on a contemporary version of an internationalist vision that is a manifestation of the "liberal rationalism" that Koskenniemi attributes to Lauterpacht and to an important strand of the discipline of public international law.

\section{Internationalist Consciousness and the Cosmopolitan Style in International Law}

In order to understand the policy vision of the international that was advanced in the tetralogy, it seems useful to explore the strong affinities of the internationalist values contained in the judgments with the belief-systems of a group of "cosmopolitan" post-Second World War public international lawyers. The Supreme Court of Canada's approach to the international system in many ways seems more familiar to public international lawyers than private international lawyers. Was the tetralogy, in effect, a diffuse conquest of private international law by the values, if not the processes, of public international law?

Recent analyses observe that many public international lawyers define their role to be part of a "project" of building international order through international law. Most international lawyers are engaged and committed to the project of expanding the domain of

${ }_{99}$ M. Koskenniemi, "Lauterpacht: The Victorian Tradition in International Law" (1997) 8 European J. Int'1 L. 2 1 5 .

$100 \mathrm{Ibid}$. at 216.

101 Ibid. at 262.

102 Ibid. at $228-33$. 
international law and institutions against the disorder of realpolitik and narrow national interests. ${ }^{103}$ For this group, international law and institutions are without question better than a world of conflict and anarchy. Especially in the twentieth century, this grouping of international lawyers and policymakers have seen their role as an attempt to minimize the possibility of the descent of the anarchic international system into war and economic depression. International lawyers, no doubt, have understood the importance of sovereignty and national polities. From the perspective of maintaining a peaceful international order, however, the problem has never seemed to be excessive constraint of national sovereignty by international law and institutions.

The focus on the idea of a single set of values shared by international lawyers can obscure the fact that there are different approaches to the achievement of international law and order. A useful map for understanding the tetralogy is suggested by David Kennedy's analysis of the "international style" in post-Second World War law and policy. Kennedy considers that the post-Second World War debate on international law and policy has involved two distinct "styles," each committed to building the international order and to countering state sovereignty, but with different emphases. ${ }^{104}$ On the one hand, "metropolitans" favour supranational institutional remedies modelled on those of the traditional nation-state, whether through the reassertion or revival of domestic institutions or, more likely, through the construction of parallel structures regulatory boards, administrators, technocracies, courts - at the international level. On the other hand, "cosmopolitans" are less concerned with looking for such "traditional" institutional remedies and, instead, believe that international order and objectives can be achieved through the operation of a diffuse regime of policymakers with a shared internationalist policy outlook. As Kennedy observes of John Jackson, a leading US international trade lawyer, the concern of cosmopolitans was less with the establishment of strong international-level institutions and more with the goal of a "widespread and vigorous liberal spirit." 105

The variation in styles does not affect the basic commitment of both cosmopolitans and metropolitans to the general idea that

${ }^{103}$ Kennedy, supra note 95 .

${ }^{104}$ D. Kennedy, "The International Style in Postwar Law and Policy" (1994) Utah L. Rev. 7 at $28-29$.

105 Ibid. at 13 . 
there should be an "internationalist" solution that advances international-level goals. Such a commitment to the building of international institutions and international law can blind internationalists to some of the concomitant dangers of their solutions and marginalize certain types of alternative policies. The consequence is that for both cosmopolitans and metropolitans, "the sense of having rejected or replaced sovereignty works, perhaps ironically, to insulate the text from actual political conflict."106

The tetralogy of the Supreme Court of Canada demonstrates well the way in which a national court could effect internationalist reform through "cosmopolitan" means. This kind of reform shows how an internationalist-minded set of national legislators, bureaucrats, and judges worldwide could effect reform that would forward internationalist objectives through a "widespread and vigorous liberal spirit." 107

A more metropolitan strand in private international law is perhaps best represented by the reform work of the Hague Conference. The conference is a good example of the eclectic mix of individuals that populate the world of policymaking in the field of private international law. The conference demonstrates a common culture of international lawyers and scholars, with similar backgrounds, training, and interests, but committed to the development of international treaties in the field of private international law. The conference has drafted numerous draft conventions, although few have significant numbers of signatories. ${ }^{108}$ Currently, the Hague Conference is the negotiating venue for efforts to reach an international convention on recognition and enforcement of judgments. ${ }^{109}$ In this process, the Hague Conference has itself been changing as it becomes subject to the hard-nosed world of trade law diplomacy and commercial interest bargaining. ${ }^{110}$

Metropolitan international law strategies such as the treaties of the Hague Conference have, so far, had limited impact on actual

106 Ibid. at 29 .

107 Ibid. at 13 .

108 The only two conventions related to commercial matters that have been widely accepted concern relatively minor subjects: see discussion in note $6 \mathrm{~g}$.

109 See von Mehren, supra note 84 .

110 Black, supra note 85 , observes that representation at these meetings is shifting from the grand old men of private international law to international trade diplomats. The latter may be more interested in the give-and-take of international negotiations than the search for common principles or issues of justice of older unification projects. 
national rules of private international law. Much more important to internationalist reform have been the decisions of particular national courts. The private international law judgments of the Supreme Court of Canada fit well into the mode of the cosmopolitan internationalist national lawmaker, attempting to promote international values even in the absence of an international legal architecture. Unlike in fields such as public international law or international trade law, it is the courts that have been the most significant source of reform in Canadian private international law. In this sense, the tetralogy provides stronger examples of legal activism in the name of the international than the work of most public international law judges or scholars, as these municipal judges are law-makers in a way that most public international lawyers are not. The private international law context also demonstrates how a decentralized process of reform can lead to similar results across jurisdictions because of the prevalence of certain types of policy arguments in the mindset of key decision-makers a kind of harmonization by shared vision and spirit.

What does this cosmopolitan spirit consist of? It continues to identify nationalism and statism as the values that pose the most serious threats of disorder. ${ }^{111}$ In particular, the internationalist professional and disciplinary class often views itself as fighting tendencies within domestic governments and populations towards parochialism and narrow self-interest. ${ }^{112}$ A lapse into parochialism jeopardizes mutually beneficial cooperation and public goods, including the benefits of international peace and a functioning international economy. The nightmare scenarios for the discipline of international lawyers are those of the interwar period, in which increasing militarism led to constant violent conflicts and eventually to world war, and economic nationalism led to the complete collapse of the trading system and economic depression. Avoiding such downward spirals is the key concern of cosmopolitan internationalists in public international law. In the tetralogy, we see the spread of these sentiments into a realm of law more removed from high politics.

One general danger of adopting the goals of public international law in private international law is that private international lawyers and most national judges hearing disputes in private international

111 See, for example, T. Franck, "Clan and Superclan: Loyalty, Identity and Community in Law and Practice" (1996) 9o Am. J. Int'l L. 359.

112 Kennedy, supra note 95 . 
law are not experts in the challenges of international conflicts and negotiations of state interests. Although gently cosmopolitan, private international lawyers and judges focus more specifically on rules justified by "lower" level concerns, such as fairness to the parties and the development of a workable scheme for domestic courts, rather than large-scale state concerns, such as peace and interstate trade. Few private international scholars and judges are familiar with the experience of public international lawyers or governmental officials engaged in security negotiations. Nor are they typically familiar with the hard-bargaining and unhappy compromises of trade law practitioners or negotiators. Many private international lawyers and judges have experienced the international as a realm of peaceful cooperation, economic exchange, cosmopolitan education, and multinational values. Ironically, this perspective may prepare the way for an uncritical embrace of internationalist values. Such an uncritical reception of internationalism is a particular danger in the Canadian context.

\section{Canadian Legal Internationalism and Canadian International Legalism}

The importance of traditions of internationalism and multilateralism in Canadian policymaking and identity-formation is also relevant to Canadian legal institutions and legal values. Contemporary Canadian lawmakers, including the judges of the tetralogy at the Supreme Court of Canada, operate in a national context that is marked by a commitment to internationalism and multilateralism. National context matters to internationalism. In the United States, international lawyers and cosmopolitan liberals, more generally, while being crucial in defining the academic discipline of international law, are largely marginal players in the mainstream of US politics and law-making. ${ }^{113}$ In contrast, what was marginal in the United States has, especially in the post-Second World War period, become more the mainstream in Canada. Internationalist policy argumentation is much more positively received in Canada. Indeed, I will argue that this more favourable view of the international lapses, at times, into a naively simple support for the international.

Foreign and international elements are pervasive in Canadian law. ${ }^{114}$ The imperial and commonwealth legacy remains very strong.

113 Ibid. at 1 7-29.

114 For a critical commentary on the sociology of a legal profession that has diminished ties to Canada, see Arthurs, supra note go. 
The availability of appeals to the Judicial Committee of the Privy Council from the Supreme Court of Canada was not formally discontinued until 1949. ${ }^{115}$ More importantly, recourse by Canadian courts, lawyers, and scholars to British and Commonwealth court decisions and scholarly writings has continued to this day. Canadian law schools include an unusual amount of foreign materials in their teaching, and many Canadian legal academics are immigrants from Britain or other Commonwealth jurisdictions or are Canadians who have studied or worked abroad. ${ }^{116}$

A number of the judges of the Supreme Court of Canada have international experience through study or work abroad. Justice La Forest, the leading judge in the tetralogy, was raised in a bilingual, bicultural environment, completed graduate work at Oxford and Yale, ${ }^{117}$ and was the author of the leading Canadian treatise on extradition. ${ }^{118}$ Justice Frank Iacobucci did graduate work in England and worked in private practice in New York. Justice Louise Arbour, recently appointed to the court, was the former chief prosecutor for the International Criminal Tribunal for the Former Yugoslavia. ${ }^{119}$ The Canadian judges participate actively in the

115 See P. Hogg, Constitutional Law of Canada, $4^{\text {th }}$ ed. (Toronto: Carswell, 1997) at section 8.2.

${ }^{116}$ For example, fourteen of the fifty-two full-time faculty at Osgoode Hall Law School in Toronto in the 1997-98 academic year received their legal training entirely outside of Canada. These included Peter Hogg, the current dean of the school and the author of the leading treatise on Canadian constitutional law, who is originally from New Zealand and was educated there and in Australia. In addition, forty-five of the fifty-two full-time faculty had at least one university degree from a non-Canadian university; Osgoode Hall Law School of York University 1997-1998 Calendar at 11-12.

117 See, generally, Johnson and McEvoy, supra note 6.

118 G.V. La Forest, Extradition to and from Canada (New Orleans: Hauser Press, 1961). The most recent edition is edited by Anne Warner La Forest, La Forest's Extradition to and from Canada, grd ed. (Aurora, ON: Canada Law Books, 1991). Justice La Forest was the leading authority at the court on extradition, and he wrote the court's judgments in a series of significant extradition cases; for example, Canada v. Schmidt, [1987] i S.C.R. 500; McVey (Re); McVey v. United States, [1992] 3 S.C.R. 475; Kindler v. Canada (Minister of Justice), [1991] 2 S.C.R. 779 [hereinafter Kindler]; Reference Re $\mathrm{Ng}$ Extradition (Can.), [1991] 2 S.C.R. 858 [hereinafter $R e N g$ Extradition]. These cases offer an interesting parallel to the private international law judgments; see Wai, supra note 6.

119 It is interesting to note the change in Justice Louise Arbour's approach to international matters as she moved from being a leading judge of Canadian criminal law to being the chief prosecutor for the International Criminal Tribunal for the Former Yugoslavia. As a domestic judge, Justice Arbour was a strong 
formal and informal networks among courts and lawyers, which one commentator has variously labelled "transjudicial dialogue," "transgovernmentalism," and "judicial foreign policy." 120 The judges travel frequently and meet with judicial counterparts from other jurisdictions. ${ }^{121}$

This personal experience of the judges of the Supreme Court of Canada may contribute to internationalist trends in the court's judgments. At the level of sources, for example, Canadian courts now regularly cite US materials ${ }^{122}$ and frequently discuss provisions of international law, ${ }^{123}$ although in a fashion that is at times haphazard. ${ }^{124}$ The tetralogy is filled with references to foreign and international materials. For example, the judgment in Morguard invokes the examples of the "full faith and credit" provisions in the United States and Australia constitutions, the European conventions on the recognition and enforcement of judgments, and the doctrine of comity in the United States. ${ }^{125}$ The judgment in Amchem

defender of the rights of the accused. For example, in the decision of the Ontario Court of Appeal in $R$ v. Finta (1992), 92 D.L.R. $4^{\text {th }} 1$, she sided with a three-justice majority, which acquitted the accused war criminal. The failure of the appeal of that judgment at a deeply divided Supreme Court of Canada effectively emasculated Canadian domestic prosecution of accused war criminals from the Second World War; R. v. Finta, [1 994] 1 S.C.R. 7ol. As chief prosecutor, the much less settled terrain of the war crimes prosecutions led to her development and advocacy of tools such as sealed indictments that it seems unlikely she would have accepted in a domestic context. Her return to Canada in 1999 as a member of the Supreme Court of Canada may see the pendulum switch back, as she may become a leading figure in a return to emphasis on underlying domestic values. For example, the Supreme Court of Canada effectively overruled Kindlerand Re NgExtradition, supranote 118 , in finding that the Canadian Charter of Rights and Freedoms did not permit extradition of Canadian suspects to a US jurisdiction without assurances that they would not face the death penalty; United States v. Burns, [2001] 1 S.C.R. 283. This is a dramatic change and reflects a quite different conception of international criminal matters than that which the court, under Justice La Forest's lead, had been pursuing just one decade earlier; see Wai, supra note 6; E. Morgan, "In the Penal Colony: Internationalism and the Canadian Constitution" (1999) 49 U.T.L.J. 447.

120 See A.-M. Slaughter, "The Real New World Order" ( 1997) 76 Foreign Affairs $18 \mathrm{~g}$ at $186-8 \mathrm{~g}$. See also Slaughter, supra note 88.

${ }^{121}$ Slaughter, supra note 120 at $\mathbf{1} 88-89$.

122 G.V. La Forest, "The Use of American Precedent in Canadian Courts" ( 1994) 46 Maine L. Rev. 211.

${ }^{123}$ See, for example, Bayefsky, supra note 88; La Forest, supra note 41.

124 See Toope, supra note 89 .

125 Morguard, supra note 1 at 1096,1098 , and 1100. 
cites and discusses the important House of Lords decisions with respect to both forum non conveniens and anti-suit injunctions. ${ }^{126}$ In contrast, even the most internationalist of US decisions ${ }^{127}$ rarely cite, let alone seriously consider, international or comparative materials. The parochialism of US courts with respect to foreign and international law has been the source of comment both outside ${ }^{128}$ and within the United States. ${ }^{129}$

The tetralogy and other international law decisions of the Supreme Court of Canada may simply reflect the significant traditions of internationalism in general Canadian policy discourse. This notion is partly due to the political and economic reality of a small national economy, which was formerly part of larger empires and more recently is highly integrated into the international economy, particularly with the United States. ${ }^{130}$ Canadian political and cultural identities have also been bound up with foreign and international matters because of significant and continuing migration. As a consequence of immigration and Canadian policies of multiculturalism, many Canadians retain strong identifications with other national cultures. ${ }^{131}$ Canadian foreign policy has involved a significant focus on multilateralism, with a strongly favourable view of international organizations and law as a place for Canada to play a "middle power" role. ${ }^{132}$ In international law, Canadian legal

126 Amchem, supra note 1 at 922-25.

127 For example, the decision of the US Supreme Court in Mitsubishi Motors Corp. v. Soler-Chrysler Plymouth Inc., 473 U.S. 614 (1985) [hereinafter Mitsubishi Motors].

128 See La Forest, supra note 122 at 21 8-20.

${ }^{129}$ See H. Blackmun, "The Supreme Court and the Law of Nations" (1994) 104 Yale L. J. 39. For a critique of the common perception that US courts are xenophobic, see K. Clermont and T. Eisenberg, "Commentary: Xenophilia in American Courts" (1996) 109 Harv. L. Rev. 1120.

${ }^{130}$ See, for example, H. Innis, The Fur Trade in Canada (New Haven: Yale University Press, 1930); H. Innis, Essays in Canadian Economic History (Toronto: University of Toronto Press, 1956); R. Naylor, Canada in the European Age 1453-1919 (Vancouver: New Star Books, 1987); K.R. Nossal, The Politics of Canadian Foreign Policy, 3 d ed., (Scarborough, ON: Prentice Hall, 1997) at 29-31.

131 See J. Holmes, The Betler Part of Valour: Essays on Canadian Diplomacy (Toronto: McClelland and Stewart, 1970); for a skeptical view, see Nossal, supra note 130 at 57 .

132 See, for example, W. Kymlicka, Multicultural Citizenship (Oxford: Clarendon Press, 1995); C. Taylor, "The Politics of Recognition," in A. Gutmann, ed., Multiculturalism (Princeton, N.J.: Princeton University Press, 1994); C. Taylor, Reconciling the Solitudes: Essays on Canadian Federalism and Nationalism (Montreal: McGill-Queen's University Press, 1993). 
academics have been significant advocates of multilateralism and the international cooperative approach. ${ }^{133}$ David Kennedy's description of international lawyers in the difficult climate of the postSecond World War United States seems even more appropriate with respect to Canadian international lawyers:

[L] egal internationalists in the United States tend to be humanist and liberal in the European sense; overwhelmingly committed to the idea that international law is a good thing, both inevitable and worth working quite hard for even against formidable odds. Their most significant disciplinary commitment is less to the politics of American liberalism than to the single idea that things go better when they go internationally. ${ }^{134}$

The strong traditions of internationalism in Canadian legal culture and in the policy community more generally do not automatically translate into internationalist legal reforms. It may be that on international matters, as in other areas, the Canadian courts operate at a lag to other Canadian institutions and to changes in Canadian social values. In Morguard, the court itself invoked this sense of law being at a lag to internationalizing tendencies in the broader society in order to bolster the case for the legal reforms undertaken in the judgment.

Hence, in the tetralogy, the court may simply be reflecting more general Canadian social values. However, courts also sometimes move in advance of broader opinion and can play a role in shaping policies and attitudes. Arguably, the Supreme Court of Canada judgments in private international law are an example of a court playing a leading role in constituting an internationalist system in both rules and values. In this role, the court can be compared to the role of the European Court of Justice in promoting the process of European integration. ${ }^{35}$ The Supreme Court of Canada's role in promoting internationalist reform is perhaps more unexpected in that this was a national court rather than an international court.

${ }^{133}$ See, for example, R. St. J. Macdonald, G. Morris, and D. Johnston, "Canadian Approaches to International Law," in R. St. J. Macdonald, G. Morris, and D. Johnston, eds., Canadian Perspectives on International Law and Organization (Toronto: University of Toronto Press, 1974) 940 at 950-54. Canadian lawyers have been prominent in international institutions; for example, John Humphrey's role in the first years of the United Nations. More recently, Canadians have figured prominently in the operation of the war crimes tribunals for Rwanda and the Former Yugoslavia; see, for example, P. Knox, "Canadian Key Players at Hague Tribunal," Globe and Mail (July 1 7, 2001 ), A1o.

134 Kennedy, supra note 95 at 23.

135 See, for example, Weiler, supra note 6. 
No doubt, the Supreme Court of Canada in the tetralogy was both reflecting and deploying an internationalist vision in a national and disciplinary context in which these values already had some resonance. In doing so, the court instituted national legal reform by deploying a powerful, but a particular, internationalist vision. In addition to many benefits thereby achieved, there are clearly dangers in this mode of internationalization. Specifically, reform in the name of the international can fail to acknowledge that there are many internationalist goals and visions. Being for the international, even in Canada, should not be a simple matter.

\section{Part 4: The Structure of Internationalist Policy Argumentation In the Tetralogy}

The previous section explained the modes of internationalism that were operating in the tetralogy of private international law cases of the Supreme Court of Canada. The following section describes in more detail the content of the particular internationalist visions advanced in the tetralogy. In the "cosmopolitan" internationalization in private international law, common structures of policy argumentation are more important than whether a decisionmaker points to binding international law treaties or institutions to explain their decisions. While imperfectly articulated sentiments towards the international might form the bulk of internationalism in "a vigorously liberal spirit," 136 I believe that this internationalist "spirit" can be described with somewhat more precision as involving a policy commitment towards some basic international values. Ultimately, these policy commitments may involve many indeterminacies and irrationalities, but they also provide the language and structure for the recognition and analysis of such indeterminacies and irrationalities.

\section{STRUCTURES OF POLICY ARGUMENT}

The policy argumentation behind the internationalist reform in the tetralogy powerfully invokes a set of political, economic, and moral arguments for an internationalist order. I believe that the policy concerns identified are associated with liberal internationalism and, in particular, policies related to international commerce, international cooperation, and cosmopolitan fairness. ${ }^{137}$

${ }^{136}$ Kennedy, supra note 104 at 13.

${ }^{137}$ Each of these policy objectives is discussed in detail in R. Wai, Commerce, Cooperation, Cosmopolitanism: Private International Law and the Public Policy Structure of 
When combined, these policy concerns provide reinforcing justifications for particular legal reforms. They have special pull when the argumentation is deployed in contexts such as a cosmopolitan disciplinary consciousness or an internationalist national tradition such as those already described.

These types of policy justification for internationalist reforms have a heritage. All three can be traced back to the traditions of liberal internationalism and can be found in the work of liberal theorists such as John Stuart Mill and Immanuel Kant. ${ }^{138}$ Liberal internationalist theorists have generated a system of reasoning about political and economic interests in which ideals of non-intervention and cooperative interaction achieved an underlying normative harmony of interests. At the political level, the ideal of non-intervention, perhaps backed up by either international institutions or the policies of powerful states, provides a means for sovereign states to achieve peace.$^{139}$ In the international economy, the ideal of a liberalized trading order replaced the mercantilist idea of conflict over a fixed set of economic goods with the liberal ideal of cooperative gains in worldwide production through international exchange and specialization based on principles of comparative advantage. ${ }^{140}$ Even imperial relations were understood through the lens of a potential harmony of interests, although rife with problematic claims about the "needs" of barbarian peoples for the political, economic, and moral resources and guidance of the West. ${ }^{141}$ Informing

Internationalism (S.J.D. dissertation, Harvard Law School, 2000) (on file at Harvard Law School Library).

${ }^{138}$ I track these arguments in John Stuart Mill's theories of international politics, international economics, and empire in R. Wai, John Stuart Mill and International Relations (M.Phil. thesis, Oxford University, 1990) [unpublished]. On liberal traditions of international relations and law, see A.-M. Slaughter, "International Law in a World of Liberal States” (1995) 6 European J. Int'l L. 503; T. Nardin and D. Mapel, Traditions of International Ethics (Cambridge: Cambridge University Press, 1992), chapters 7, 8, 10, and 12.

${ }^{139}$ See, for example, J.S. Mill, "A Few Words on Non-Intervention" (1859) in J.M. Robson, ed., Collected Works of John Stuart Mill (Toronto: University of Toronto Press, 1963-91 ), vol. XXI, Essays on Law, Equality, and Education, 109.

140 See, for example, J.S. Mill, The Principles of Political Economy, 7 th ed. (London: Longmans, Green and Company, 1909), Book III, chapters 17 and 18.

${ }^{141}$ See, for example, J.S. Mill, Considerations on Representative Government (1861) chapter XVIII ("Of the Government of Dependencies by a Free State"), in Robson, supra note 139, vol. XIX, Essays on Politics and Society; J.S. Mill, "Wakefield's The New British Province of South Australia," in Robson, supra note 139, vol. XXII, Newspaper Writings, 738; J.S. Mill, "England and Ireland," in Robson, supra 
all of these concerns was a moral cosmopolitanism linked to a liberal individualism, which prioritized the rights or at least the interests of the individual over claims of nation, community, or the collective. ${ }^{142}$

As discussed earlier in this article, these liberal internationalist values of international commerce, cooperation, and cosmopolitanism have deep foundations in the discipline of public international law. Joseph Weiler observes that similar objectives of "prosperity, peace and supranationalism" were at work as "foundational ideals" in the building of the European Union. ${ }^{143}$ For a Europe devastated by the political and economic catastrophes of the world wars, European integration was oriented towards the basic ideals of peace and prosperity. As to "supranationalism," Weiler means less a commitment to any particular institutional structure and more a sense, consistent with Enlightenment liberalism, in which the treatment of individuals would not depend on their state citizenship. ${ }^{144}$

\section{CHARACTERIZING INTERNATIONALIST REFORM: COMMON FEATURES OF INTERNATIONALIST REFORM}

Although each of the doctrinal reforms in the tetralogy has distinctive features, some common characteristics do emerge. The connections between these doctrinal reforms have been observed by both supporters and critics. ${ }^{145}$ At least four common characteristics of the reforms can be identified: an emphasis on greater certainty and predictability in rules (certainty), the promotion of

note 139 , vol. VI, Essays on England, Ireland, and the Empire, 5 o5; Mill, supra note 14 o, Book II, c. 13 .

${ }_{142}$ The state or community instead is justified as instrumental to the interests or rights of individuals, rather than as an end in itself; see Wai, supra note 138 at c. 1 .

${ }^{143} \mathrm{~J}$. Weiler, The Constitution of Europe (Cambridge: Cambridge University Press, 1999) at $23^{8-4}$.

${ }_{144}$ Ibid. at $25^{2}$.

${ }^{145}$ See, for example, J.J. Fawcett, ed., Declining Jurisdiction in Private International Law (Oxford: Clarendon Press, 1995); T. Carbonneau, "Mitsubishi: the Folly of Quixotic Internationalism" (1986) 2 Arbitration Int'l 116 at 125; A. Lowenfeld, International Litigation and the Quest for Reasonableness (Oxford: Clarendon Press, 1 996); J. Paul, "Comity in International Law" (1991) 32 Harv. Int'l L. J. 1. Paul groups many of these reforms under his more expansive definition of "comity." I believe that comity is more narrowly concerned with interstate cooperation, and so I prefer the term "internationalist policy" for the range of economic, political, and moral arguments required to support a practice of comity. 
common standards across jurisdictions (uniformity), an increased deference to foreign laws and processes (comity), and a greater enforcement of party autonomy (autonomy).

First, a number of the reforms are intended to increase certainty and predictability in the rules and processes of private international law. For example, the move in Tolofson to choice of law rules based on the lex loci delicti arguably has the virtue of setting a rule that is simpler than one based on multiple different considerations and exceptions. Regular enforcement of foreign judgments as envisaged by Morguard is thought to assist parties to understand that they should defend foreign suits unless there is very clearly a lack of connection of the foreign jurisdiction to the action. Multilateral conventions, such as the Convention on Jurisdiction and the Enforcement of Judgments in Civil and Commercial Matters (Brussels Convention), ${ }^{146}$ increase certainty by setting uniform grounds for jurisdiction and recognition and enforcement, and by reducing judicial discretion to stay actions or to refuse to recognize and enforce.

Second, the tetralogy's efforts to reform Canadian private international law in accordance with foreign practices can promote the objective of increasing the uniformity of private international law rules. Existing conventions, such as the New York Convention, as well as proposed conventions, such as the Hague Conference discussions with respect to recognition and enforcement of judgments, would clearly increase uniformity of private international law rules across jurisdictions. In Tolofson, the Supreme Court seemed to consider that a common rigid rule of choice of law in tort would help to control for variations in applicable laws that would invite forum shopping and cause uncertainty. ${ }^{147}$ The turn to constitutionalization, which is suggested in Morguard and expressly decided in Hunt, places limits on the ability of provincial courts and legislatures to adopt completely different rules.

Third, the reforms share a policy of comity, in the sense of a greater respect and deference for the jurisdiction, the substantive laws, and the judgments of foreign jurisdictions. The eased standards for stays of actions based on forum non conveniens, the greater facility of recognition and enforcement, the discouragement of antisuit injunctions, the use of choice of law rules based on factors other than the interest-analysis of the forum state, all involve municipal

${ }^{146}$ Brussels Convention, supra note 83 .

147 Tolofson, supra note $\mathbf{1}$ at 1052. 
courts revising their approach to international cases in order to better recognize the laws and the courts of other jurisdictions.

Fourth, the reforms in the tetralogy reinforce party autonomy in dispute resolution. The restrictions on anti-suit injunctions set out in Amchem and the emphasis on comity in recognition and enforcement of foreign judgments articulated in Morguard increase the effectiveness of the choice by plaintiffs as to where to proceed with litigation. The tetralogy also occurs against a backdrop, most pronounced with respect to international arbitration, in which Canadian courts are increasingly reluctant to interfere with disputeresolution processes that are agreed to by parties. Choice of law, forum selection, and arbitration clauses are increasingly supported by national courts. ${ }^{148}$

These general characteristics of internationalist reform in private international law are not very compelling as ends in themselves. For example, neither deference to foreign courts nor predictability of rules would seem to be worthwhile on their own. Rather, laws with such characteristics are justified because they serve more fundamental normative objectives. While the ultimate justification or motivation for any actual legal decision or legal reform is complex and can always be disputed, I posit significant explanatory power in background political, economic, and moral objectives related to the international system. An understanding of internationalist policy argumentation is an important part of contemporary policy debate in private international law and a significant concern and challenge for effective advocacy in the field.

\section{COSMOPOLITANISM AND ANTI-PAROCHIALISM}

The judgments of the tetralogy argue strongly for a cosmopolitan spirit in common law adjudication with respect to matters that cross provincial and national borders. In Morguard, ${ }^{149}$ for example, the court stated that contemporary private international law should reject a parochial inclination to act only as if in a bounded world.

Traditional private international law is an easy target for a cosmopolitan critique because in its sources and orientation it is clearly a kind of municipal law. In terms of sources, issues of private international law are not, as has been discussed earlier, the subject

148 See J-G. Castel and J. Walker, eds., Canadian Conflict of Laws, $5^{\text {th }}$ ed. (Toronto: Butterworths, 2002) at sections 13.7 (forum selection), 31.2(a) (express choice of law in contract), $15 \cdot 3^{-1} 5 \cdot 4$ (arbitration clauses).

${ }^{149}$ Morguard, supra note 1 at 1098 . 
of either customary public international law or conventional public international law. Rather, domestic legislatures, and, in common law jurisdictions, the courts, have been the source of relevant laws. ${ }^{150}$ In addition, in terms of policy orientation, private international law has focused on the policy concerns of the jurisdictions in which the courts or legislatures are situated. For example, the limited "public policy" exception in the common law rules on recognition and enforcement has been oriented towards the public policy of the court considering recognition, not the public policy concerns of foreign jurisdictions. ${ }^{151}$

Non-domestic concerns have played an indirect role in traditional private international law. Sometimes this role has been played through doctrines, such as the comity concerns of Joseph Story, which are thought to also be in the long-term self-interest of the jurisdiction in question. ${ }^{152}$ At other times, cosmopolitan interests have, intentionally or not, been protected through rules, such as the vested rights approach of A.V. Dicey, which shift the focus away from domestic interests and onto the formal characteristics of different legal relations. ${ }^{153}$ As often, cosmopolitanism has been a form of critique that has hovered over policy debate in private international law, calling on legislators and adjudicators to act in a non-parochial "spirit." It is this kind of reforming spirit that is brought to the fore in the tetralogy.

Cosmopolitanism argues that policymakers take a normative standpoint that includes the interests and values of individuals and societies outside of a defined state jurisdiction. ${ }^{154}$ The cosmopolitan view argues that it is improper to restrict one's normative judgments to a consideration of the interests and values of the home jurisdiction. This normative approach, which has been associated with moral and political theories from natural law through global liberalism, rejects the identification of normative boundaries with juridical boundaries. A liberal theory of rights, for example, would

${ }^{150}$ Dicey $\mathcal{E}^{\mathcal{O}}$ Morris, supra note 92 at 1-2; Castel, supra note 10 at $4-5$.

${ }^{151}$ See, for example, Dicey $\mathcal{E}^{2}$ Morris, supra note 92 at 88-91.

152 In J. Story, Commentaries on the Conflict of Laws (Boston: Hilliard, Gray and Company, 1834) at 34, Joseph Story notes that comity was based on the idea of laws which arise from mutual interest and utility, from a sense of the inconveniences that would result from a contrary doctrine, and from a sort of moral necessity to do justice in order that justice may be done to us in return.

${ }^{153}$ A.V. Dicey, A Digest of the Law of England with Reference to the Conflict of Laws (London: Stevens and Sons, 1896 ).

154 T. Pogge, "Cosmopolitanism and Sovereignty" (1992) 103 Ethics 48. 
question whether an individual with weak connections to the jurisdiction of a court and, hence, who is unable to vote or otherwise participate in the polity, is properly subject to the authority of the state's legal institutions. ${ }^{155}$

Such general theories of morality are sometimes useful in legal debate. They act as a reminder to state actors, such as common law judges, to consider more broadly the way in which moral obligations do not end at the border. To use Justice La Forest's phrase from the international criminal law context, "we are all our brother's keeper." 156 The claims of cosmopolitan concern are especially powerful as the number of social, political, economic, and cultural ties that cross borders increase due to the dramatic changes in communications, transportation, migration, and markets that we associate with globalization. ${ }^{157}$

Obviously, there is a limit to what cosmopolitanism can offer in terms of legal decision-making. The basic problem is simply that moral arguments of cosmopolitanism provide limited institutional guidance. As Thomas Pogge observes, moral cosmopolitanism does not equate to legal cosmopolitanism. ${ }^{158}$ Moral cosmopolitanism is concerned with the belief "that all persons stand in certain moral relations to one another: we are required to respect one another's status as ultimate units of moral concern - a requirement that imposes limits on our conduct and, in particular, upon our efforts to construct institutional schemes." 159 This moral position may or may not support legal cosmopolitanism, which Pogge defines as involving "a concrete political ideal of a global order under which all persons have equivalent legal rights and duties, that is, are fellow citizens of a universal republic." ${ }^{160}$ It seems clear that various

${ }^{155}$ Brilmayer, supra note 55 at 206.

${ }_{156}$ R.v. Libman, [1985] 2 S.C.R. 178 at 213-14.

${ }^{157}$ See, for example, A. von Mehren and D. Trautman, "Recognition of Foreign Adjudications: A Survey and A Suggested Approach" (1968) 81 Harv. L. Rev. 1601 at 1603 :

The ultimate justification for affording some degree of recognition is that if in our highly complex and interrelated world each community exhausted every possibility of insisting on its parochial interests, injustice would result and the normal patterns of life would be disrupted.

The court in Morguard quotes this passage, supra note 1 at 1097.

${ }_{158}$ Pogge, supra note 154 at $48-49$.

159 Ibid.

160 Ibid. at 49 . 
kinds of institutional arrangements are consistent with moral cosmopolitanism. For example, instead of supranational government, cosmopolitans might also support the growth of international organizations or transnational processes such as the international market, telecommunications, and transportation, each of which seems to bypass governance through traditional forms of government. ${ }^{161}$ Alternatively, some cosmopolitans believe that the creative use of international markets and transnational civil society networks can be combined with the preservation of the nation-state system to present an alternative to the need for supranational institutions or law. ${ }^{162}$

It follows that it is difficult to determine the implications of moral cosmopolitanism for specific doctrines of private international law. In order to generate more specific institutional recommendations, it seems that the cosmopolitanism expressed in the tetralogy is linked to, and identified with, two other general policy goals that are central commitments of liberal internationalism: on the economic level, support for international commerce and trade and, on the political level, support for interstate cooperation and comity.

\section{TRADE AND COMMERCE}

The internationalist reform in the tetralogy brings the discourse of international commerce into the area of private international law. In Morguard, for example, Justice La Forest, in a key passage, writes that " $[t]$ he business community operates in a world economy even in the face of decentralized political and legal power. Accommodating the flow of wealth, skills and peoples across state lines has become imperative." ${ }^{63}$ In Tolofson, Justice La Forest again invokes contemporary international economic order, and observes that "[s] tability of transactions and well grounded legal expectations must be respected." 164 The choice of a rigid choice of law rule of lex loci delicti was informed by the supposed value of a predictable and clear rule for the purposes of economic planning. Similarly, in Hunt, Justice La Forest observed that one of the problems of a

\footnotetext{
161 This corresponds to the cosmopolitans identified by Kennedy, supra note 104 at 13 .

162 See, for example, Slaughter, supra note 120.

163 Morguard, supra note 1 at 1096.

164 Tolofson, supra note 1 at 1051.
} 
blocking statute was that "it discourages international commerce and efficient allocation and conduct of litigation." ${ }^{65}$

The view that reform of traditional private international law is needed to promote international commerce is found in other internationalist reform venues, such as in the support for the Brussels Convention and the Convention on the Law Applicable to Contractual Obligations (Rome Convention) in Europe, ${ }^{166}$ and in the push at the Hague Conference for a multilateral convention on jurisdiction and recognition and the enforcement of judgments. ${ }^{167}$ The policy objective of promoting international commerce has registered as a powerful rhetorical tool even in jurisdictions where internationalist arguments normally are not persuasive. ${ }^{168}$ The objective clearly impacts on other areas of law as well, such as with respect to doctrines concerning the commercial activity exception to sovereign immunity. ${ }^{169}$

International commerce is also increasingly advocated as an important policy objective among scholars and theorists of private international law. Although commercial concerns were often considered of secondary significance, the objective of facilitating international commerce was a long-established public policy goal in the foundational scholarship in private international law, for example,

${ }^{165}$ Hunt, supra note 1 at 327 .

166 Brussels and Rome Conventions, supra note 83. See, for example, Report on the Convention on the Law Applicable to Contractual Obligations, 1979 O.J. (C59) 1, 4-5 (Giuliano-Lagarde Report), reprinted in R. Plender, The European Contracts Convention: The Rome Convention on the Choice of Law for Contracts, Annex V (London: Sweet and Maxwell, 1991); Dicey $\mathcal{E}^{2}$ Morris, supra note 92 at 1195 . For this view of the European regime, see $\mathrm{R}$. Brand, "Recognition of Foreign Judgments as a Trade Law Issue: The Economics of Private International Law," in J. Bhandari and A. Sykes, eds., Economic Dimensions in International Law: Comparative and Empirical Perspectives (Cambridge: Cambridge University Press, 1997) 592.

${ }^{167}$ See, for example, Black, supra note 85 .

${ }^{168}$ See, for example, the United States Supreme Court decision in Mitsubishi Motors, supra note 127 at 629-39 (per Blackmun J.). For a discussion of this case, Morguard, and the policy discourses of liberal internationalism, sce R. Wai, "Transnational Liftoff and Juridical Touchdown: The Regulatory Function of Private International Law in an Era of Globalization" (2002) 40 Colum. J. Transnat'l Law 209 at 224-29.

${ }^{169}$ See R. Wai, "The Commercial Activity Exception to Sovereign Immunity and the Boundaries of Contemporary International Legalism," in C. Scott, ed., Torture as Tort: Comparative Perspectives on the Development of Transnational Human Rights Litigation (Oxford: Hart, 2001) 213. 
in the work of Ulrik Huber ${ }^{170}$ and Joseph Story. ${ }^{171}$ Nonetheless, traditional private international law regimes have often been described by contemporary scholars as commercially dysfunctional. ${ }^{172}$ Such writers criticize the system of national court adjudication as an archaic process that is based on sovereigntist conceptions that do not attend to the realities and the needs of the contemporary international economy. ${ }^{173}$

In contemporary policy discourse, the concern for international commerce connects two well-established sets of theoretical ideas, which are familiar policy objectives in other fields of law such as international trade regulation and the laws of international business transactions. ${ }^{174}$ First, theorists concerned with international trade fear that national courts act as protectionist actors who use the play in the laws to advance national interests rather than the mutually beneficial objective of facilitating international transactions according to theories of comparative advantage. ${ }^{175}$ Second, efficiency analysis and transaction cost analysis suggest that the patchwork of national conflict of laws regimes, in addition to the disparities in the underlying substantive laws of states, generate costly uncertainty, ${ }^{176}$ lead to overlapping litigation processes that waste resources, and permit forum-shopping and other kinds of strategic behaviour by individual parties. ${ }^{177}$

170 U. Huber, De Conflictu Legum, translated in D.J. Llewelyn Davies, "The Influence of Huber's De Conflictu Legum on English Private International Law" (1937) 18 Brit. Y.B. Int'l L. 49 at 65-66.

171 Story, supra note $15^{2}$ at 34 . See more generally, D. Bederman, "Compulsory Pilotage, Public Policy and the Early Private International Law of Torts" (1990) 64 Tulane L.Rev. 1033 .

172 See, for example, Brand, supra note 166; M. Pryles, "Tort and Related Obligations in Private International Law" (1991) 227 Rec. des Cours 9.

173 See, for example, Pryles, supra note 172 at 28 .

174 Brand, supra note 166 , pairs these two kinds of arguments in advocating liberalized rules on recognition of judgments.

${ }^{175}$ See, for example, Brand, supra note 166 at $613^{-2} 6$.

176 This concern is, of course, connected to the perpetual debate in most areas of law concerning the value of rules versus standards and certainty versus flexibility. See, for example, P. Hay, "Flexibility versus Predictability and Uniformity in Choice of Law: Reflections on Current European and United States Conflict Law" (1991) 226 Rec. des Cours 281.

177 See, for example, M. Whincop and M. Keyes, Policy and Pragmatism in the Conflict of Laws (Aldershot UK: Ashgate, 2001) c. 8. 


\section{Transaction Costs}

Theoretical support for internationalist reform of private international law is partly based on economic arguments that aggregate economic benefits are maximized by rules that promote predictability and uniformity and that thereby reduce transaction costs. ${ }^{178}$ Reforms that increase uniformity and predictability are also thought to control the wasteful litigation costs associated with forumshopping by plaintiffs.

Uncertainty makes it difficult to assess risk accurately, and, therefore, uncertainty increases transaction costs. ${ }^{179}$ When risks are ascertainable, it is claimed, parties are able to allocate risks between themselves and undertake planning in that light, for example, through insurance, diversification, or reserve provisions. ${ }^{180}$ However, an adequate assessment of risk is not always possible because of imperfect information. Uncertainty may prevent parties from allocating risks between themselves or to third parties in an optimal way. ${ }^{181}$ In any event, risk assessment and allocation is not costless. Complex or unascertainable risk increases the cost of most transactions (for example, through the amount of an insurance premium), and it may prevent altogether some marginal transactions.

The objective of reducing transaction costs is served, it is claimed, by doctrinal reforms such as the clear international allocation of jurisdiction. In one such view, jurisdiction should be assumed only by the courts with the most significant connections to the dispute, a goal that is served by treaties such as the Brussels Convention and by doctrines such as forum non conveniens. Restraint by courts in assuming jurisdiction would restrict suits proceeding in multiple

178 Transactions costs analysis in law builds from the foundational work of Ronald Coase; see, for example, R. Coase, The Firm, the Market, and the Law (Chicago: University of Chicago Press, 1988 ).

${ }^{179}$ See, for example, D.C. North, Institutions, Institutional Change and Economic Performance (Cambridge: Cambridge University Press, 1990) at 126.

${ }^{180}$ The importance and complexity of insurance for risk in international commerce is discussed in V. Haufler, Dangerous Commerce: Insurance and the Management of International Risk (Ithaca, NY: Cornell University Press, 1997).

${ }^{181}$ This could be done through contractual allocation between the parties, diversification, or insurance. The idea that parties cannot and do not allocate unknown risks has been disputed; see, for example, G. Triantis, "Contractual Allocations of Unknown Risks: A Critique of the Doctrine of Commercial Impracticability" (1992) 42 Univ. Toronto. L.J. 45 o; for a compromise view, see M. Trebilcock, The Limits on Freedom of Contract, (Cambridge, MA: Harvard University Press, 1993) at $127-28,138$, and 144 . 
jurisdictions or in jurisdictions with weak connections to the dispute and, thereby, would reduce litigation costs such as lawyers fees, travel costs, and time lost for witnesses and parties to attend process. Furthermore, both clear rules allocating jurisdiction and restraint through doctrines such as forum non conveniens would reduce the costs associated with the strategic behaviour related to the determination of the most appropriate jurisdiction.

Efficiency is also arguably served by respect for party choice of law and forum selection clauses, clear rules concerning choice of law, and easy recognition and enforcement of foreign judgments and arbitral awards across state borders. These reforms increase predictability and permit parties to formulate expectations and plan for contingencies arising out of potential legal disputes. ${ }^{182}$ In addition, greater predictability will act as an incentive for parties to make rational assessments of the likelihood of success of different jurisdictional strategies and, hence, deter frivolous suits with limited likelihood of success.

Uniformity of rules across jurisdictions is also thought to reduce transaction costs by reducing the range of possible outcomes and easing the assessment of risks. The ideal would be the standardization of rules promoted by the implementation of international conventions, such as the New York Convention with respect to foreign arbitral awards or the Brussels or Rome Conventions in Europe. However, convergence on doctrines such as forum non conveniens would also serve this purpose.

Finally, granting parties to business transactions the autonomy and flexibility to structure their relations through contractual provisions such as choice of law and forum selection clauses might permit them to increase predictability and also to allocate risks optimally. Enforcing party choice as to private international law issues allows parties to make more predictable their potential liabilities, to reduce costly and inconvenient uncertainty, and to plan transactions and insurance accordingly. ${ }^{183}$ More generally, reformist writers identify arbitration and other forms of alternative dispute resolution as a superior mode for resolution of international private disputes. ${ }^{184}$ They link such forms to the lex mercatoria that

182 P. Nygh, "The Reasonable Expectations of the Parties as a Guide to Choice of Law in Contract and Tort" (1995) 251 Rec. des Cours 268.

${ }^{183}$ North, supra note 60 at 183 .

${ }^{184} \mathrm{~J}$. Jackson, W. Davey, and A. Sykes, eds., Legal Problems of International Economic Relations, 3rd ed. (St. Paul, MN: West Publishing, 1995) at 73-81. 
was developed in the period before the rise of the modern nationstate. ${ }^{185}$ Party autonomy over dispute resolution is argued to limit defects of national court systems such as unpredictability over the applicable laws, the possibility of bias, and uncertainty over the quality and expertise of adjudicators.

\section{Promoting International Trade}

In addition to the objective of minimizing transaction costs in international commerce, internationalist reform to private international law rules also draws on the concern in international trade theory of achieving the aggregate benefits of international trade based on comparative economic advantage rather than trade dictated by the narrow interests protected by juridical boundaries of states. Rules of private international law and private law can be argued to operate as barriers to trade according to comparative advantage. International trade regulation has traditionally been most concerned with trade barriers involving border measures such as tariffs and quotas. However, as the international trade regulation regime has extended in scope and depth, regulation has become increasingly concerned with domestic policies that have either the aim or the effect of obstructing international trade such as internal taxes, intellectual property laws, technical standards, and health and safety regulations. ${ }^{186}$

The concern with domestic policies plausibly extends to private law and private international law. Private law and civil procedures may be governmental measures that have the purpose or the effect of discriminating against foreign producers in order to protect domestic producers. State legislatures and courts may favour domestic economic interests in a way that is harmful not just to particular foreign interests but also to global economic welfare. ${ }^{187}$

${ }^{185}$ See, for example, L. Trakman, The Law Merchant: The Evolution of Commercial Law (Littleton, CO: Fred B. Rothman, 1983).

${ }^{186}$ See, for example, J. Jackson, The World Trading System: Law and Policy of International Economic Relations, 2nd ed. (Cambridge, MA: MIT Press, 1997) at 130; F. Roessler, "Diverging Domestic Policies and Multilateral Trade Integration," in J. Bhagwati and R. Hudec, Fair Trade and Harmonization: Prerequisites for Free Trade? vol. 2 (Cambridge, MA: MIT Press 1996) 21.

187 The potential links of private law and international trade are raised by the challenge in Loewen Group Inc. and Raymond Loewen v. United States of America, ICSID Case No. ARB(AF) $/ 98 / 3$, Notice of Claim, October 3o, 1998 [hereinafter Loewen v. United States] under Chapter 11 of the North American Free Trade Agreement, December 17, 1992, Can T.S. 1994 No.2, (1993) 32 I.L.M. 605 
Protectionism through private international law could come in various forms. For example, a court might decide whether or not to assume jurisdiction based on whether a plaintiff or defendant is from the jurisdiction. A court may be motivated to protect domestic interests in applying a choice of law rule rather than by attempting to figure out which substantive rule would be the most appropriate from an efficiency or regulatory perspective. Similarly, a jurisdiction might restrict recognition and enforcement of foreign judgments against defendants from its own jurisdiction, either through a blanket rule or through biased application of a discretionary standard.

The Québec legislation considered in the Hunt case seems, from an international trade perspective, to have been enacted for a protectionist purpose. As the Supreme Court of Canada noted, blocking statutes of this kind are intended to discourage suits in foreign jurisdictions against domestic defendants by making it procedurally more difficult for the foreign suit to proceed by, for example, impeding discovery or document production. ${ }^{188} \mathrm{~A}$ more familiar example is found in the disputes between the United States and other jurisdictions concerning the enforcement of judgments obtained under the private litigation of antitrust suits. Many foreign jurisdictions have refused to enforce such judgments and, indeed, have legislated "clawback" provisions that permit defendants to recover any damages awarded to the plaintiffs in foreign antitrust litigation. ${ }^{189}$ While genuine differences concerning antitrust policy are at stake, at least part of the concern of foreign governments is the effect of foreign antitrust laws on the economic welfare of businesses and industries based in their jurisdictions. Internationalist reforms can be partly viewed as attempts to ensure that such strategic behaviour does not occur through the mechanisms of private international law.

The most effective discipline on economic protectionism through private international law would be a binding international treaty among states such as the Brussels Convention. Short of such conventions, reforms with the characteristics of the tetralogy might

[hereinafter NAFTA]. This case is discussed later in this article under the heading "Recognition and Enforcement of Judgments: The Example of US Punitive Damage Awards."

188 Hunt, supra note 1 at 327-28.

189 See, for example, Protection of Trading Interests Act 1980, s. 6 (U.K.); Foreign Extraterritorial Measures Act, R.S.C. 1985 , c. F-29, s. 9. 
be justified as a partial control against protectionism. For example, protectionism could be discouraged through predictable rules such as the rigid lex loci delicti rule from Tolofson and through the use of forum non conveniens restraints as in Amchem. Similarly, respect for the choices of parties with respect to choice of law, forum-selection, and arbitration are thought to limit the potential biases of national courts to engage in sub rosa favouritism towards parties with domestic connections.

\section{INTERSTATE COOPERATION}

The objective of international trade according to comparative advantage is connected to perhaps the central internationalist policy objective of promoting interstate cooperation. The goal of cooperative interstate relations has figured less prominently in private international law, but the tetralogy has re-emphasized orderly and friendly inter-jurisdictional relations.

Cooperation in public international law is commonly used to support various forms of international institutions or treaties. In private international law, this awareness of inter-jurisdictional relations has been more associated with the spirit of comity. Comity would serve the purpose of promoting interstate cooperation through increased deference to foreign laws, through more restraint in assumption of jurisdiction, and through greater willingness to recognize foreign judgments. It is also reflected in the restrictions on the use of pre-emptive procedural tactics such as anti-suit injunctions, as in Amchem, or blocking statutes, as in Hunt.

Comity, which had not featured prominently in Canadian law, was elevated to a key principle of private international law in the Morguard decision. ${ }^{190}$ Subsequently, the comity principle, and often the same quote from Morguard, has been repeated in lower court judgments and in other Supreme Court of Canada judgments, including the tetralogy. For example, in Amchem, Justice Sopinka quoted from Morguard for the proposition that comity would limit the use of anti-suit injunctions, ${ }^{191}$ and he proceeded to conclude that the failure to respect comity was what might invite an anti-suit injunction from a Canadian court. ${ }^{192}$ The constitutional analysis

\footnotetext{
190 Morguard, supra note 1 at $1096-97$.

191 Amchem, supra note 1 at 913-14.

192 Ibid. at 934
} 
of the blocking statute in Hunt also fixes on the "central" idea of comity from Morguard. ${ }^{193}$

The concerns for comity and cooperation are partly a concern with rationalizing unseemly and dangerous battles between different state courts. More importantly, it is based on a sense that cooperation is to the mutual benefit of all jurisdictions involved. Among these cooperative benefits would be the benefits of international commerce described earlier, but they also extend beyond commercial interests.

\section{RegulatingInterstate Dispute Settlement}

Nothing is as central to public international law as the objective of an international process that will avoid recourse to armed conflict for settlement of international disputes. The concern with cooperative international process is also central to the effort of international trade law regimes to develop a multilateral process to replace the harmful spiral of unilateral tit-for-tat retaliation that undermines the cooperative benefits of liberal free trade.

There is a tendency to uncritically identify expanding legalistic process, even in fields such as private international law, with the greater achievement of interstate peace. A focus on legalistic court adjudication may distract attention from alternative international dispute settlement processes. Support for international legal process also has the tendency to abstract from the substantive justice of the underlying dispute. Nonetheless, the conduct of international relations through peaceful means remains a powerful basic justification for international law. ${ }^{194}$

\section{Realizing Cooperative Benefits}

The basic concern that interstate disputes be resolved by peaceful means is further augmented by the idea that cooperative institutions and binding rules assist the achievement of uncontroversial, mutually beneficial objectives. The challenge of international

193 Hunt, supra note 1 at 32 1-27.

194 It is arguably the achievement of this effect that informs all the obfuscation of doctrine, process, and institutions that David Kennedy has identified as being central to international law; D. Kennedy, International Legal Structures (BadenBaden: Nomos Verl.-Ges., 1987). The important objective is that states, for all the obscurities introduced by international law doctrine and process, are at least arguing about their concerns in terms of law and in legal institutions, rather than in terms of, and using the instruments of, pure power. 
anarchy, in which there is no overarching authority over states, is that sovereign states may fail to realize cooperative benefits, such as the productive gains of liberal free trade or international peace. A common way to explain the cooperative benefits objective in private international law is to use game theory models that have been widely applied in international relations. ${ }^{195}$ For example, Larry Kramer and Lea Brilmayer deploy classic game theory models, such as Prisoner's Dilemma, the Stag Hunt, and the Game of Chicken, to illuminate choice of law problems. ${ }^{196}$ These simple games are intended to model situations where short-term self-interest will lead participants towards outcomes that are less favourable to each of them than if they cooperate. Cooperation is impeded by the lack of trust and the absence of a coordinating authority to ensure that the other side does not cheat. In this context, parties are not able to make and enforce credible commitments to each other.

In the choice of law situation, for example, a game theoretic model suggests that autonomous states, through their own courts and perhaps under the instruction of legislatures, will define their own interest. Following the many choice of law approaches that lead them to prefer their own self-interest, they will apply forum law. If each jurisdiction makes this decision, however, there may be situations where all sides do less well than they would if each was less rigid in guarding its particular interest in every case. If appropriate institutions were developed, a court in State A might apply the law of State B in some situations in order that, in other situations, State B might apply the law of State A where State A may have a greater interest.

The best institutional solution would be a binding arrangement, such as an international treaty like the Brussels Convention, which

${ }^{195}$ L. Kramer, "Rethinking Choice of Law" (1990) 9o Columbia L. Rev. 277 at 339-45; Brilmayer, supra note 55 at c. 4 . For an early example of the use in international law of game theory models taken from international relations, see K. Abbott, "Modern International Relations Theory: A Prospectus for International Lawyers" (1989) 14 Yale J. Int'l L. 335.

${ }^{196}$ Brilmayer, supra note 55 at 156 . Modern game theory builds from the work of J. Von Neumann and O. Morgenstern, Theory of Games and Economic Behavior (Princeton, NJ: Princeton University Press, 1944). For the classic expositions of game theory and international relations and the texts most influential in international law, see T. Schelling, The Strategy of Conflict (Cambridge, MA: Harvard University Press, 1960) and R. Axelrod, The Evolution of Cooperation (New York: Basic Books, 1984). More generally on the use of game theory in law, see D. Baird, R. Gertner, and R. Picker, Game Theory and the Law (Cambridge, MA: Harvard University Press, 1994). 
commits each state to act in a cooperative fashion. Similarly, federal constitutional provisions, such as the United States "full faith and credit" clause, permit parties to act cooperatively since states are committed to act in less parochial ways and other states can rely on such constrained behaviour. This kind of discipline is arguably what the Supreme Court of Canada is achieving through the constitutionalization of some limits on conflict of laws rules in Morguard and in Hunt.

Without such treaty-based or constitutional disciplines, principles of comity might encourage a rough form of reciprocity and cooperation. ${ }^{197}$ Reciprocity is especially useful where there are repeated interactions and different states can get a better sense of which other states can be relied on to cooperate. ${ }^{198}$ However, the difficulties for this sort of reciprocity are numerous, including insufficient iterations of the game, inadequate information on each state's interests or preferences, free rider problems, difficulties in monitoring defection, and complexities in coordinating judges within each state. ${ }^{199}$ Nonetheless, cooperative benefits can be achieved in a "diffuse" manner and, over time, courts may genuinely take better account of the interests of foreign parties and jurisdictions, whether through notions of comity or doctrines that focus more on neutral factors such as vested rights. ${ }^{200}$ In addition, emerging norms of cooperation, such as the comity doctrine or a rigid lex loci delicti rule with respect to tort, might provide "focal point solutions" for coordination. ${ }^{201}$ This kind of rough reciprocity may be what the court was looking for in Amchem before granting an anti-suit injunction when it explored whether the foreign court had failed to observe the principles of comity with which Canadian courts were concerned. ${ }^{202}$

\footnotetext{
197 Brilmayer, supra note 55 at $184-87$; Axelrod, supra note 196.

198 Kramer, supra note 195 at $342-44$.

199 Ibid. at 343 , n. 228.

${ }^{200}$ Brilmayer, supra note 55 at $188-89$ (contrasting "diffuse reciprocity" to "specific reciprocity"); Kramer, supra note 195 at 344 , discusses the interesting example of the development of rules with respect to the recognition of foreign judgments in the pre-revolutionary era in the United States.

201 Brilmayer, supra note 55 at 185 . The concept is developed by Schelling in The Strategy of Conflict, supra note 196 ; Kramer, supra note 195 . See also L. Kramer, "More Notes on Methods and Objectives in the Conflict of Laws" (1991) 24 Cornell Int'l L. J. 245.

202 Amchem, supra note $\mathbf{1}$ at 934.
} 


\section{Convergence}

The argument for achieving cooperative benefits even without binding international or constitutional laws is reinforced by a belief in the convergence in both the underlying private laws and the private international law rules of different jurisdictions around the world. Convergence in the laws and values of different jurisdictions seems to make it empirically more likely and morally more justified for courts to engage in a practice such as comity. In Tolofson, for example, the notion of convergence in applicable laws suggested to Justice La Forest that plaintiffs and defendants would not have much at stake in the different choice of laws. ${ }^{203}$ In Morguard, a faith in shared basic values helps to explain why, with respect to rules of jurisdiction and recognition and enforcement, it would not really matter which court considered a claim so long as it had a real and substantial connection to the dispute. ${ }^{204}$

Such arguments recall theories of international relations that argue that a fundamental underlying convergence of values among states should make a difference to interstate relations. In particular, theorists developing insights from Kant have argued that liberal states infrequently go to war with other liberal states. ${ }^{205}$ With respect to law, it is argued that, similarly, a convergence in domestic laws and values should lead to a distinctive pattern of international legal relations. Anne-Marie Slaughter, for example, contends that among liberal states there is more room for transnational dialogue among courts, with increased borrowing, cooperation, and comity. ${ }^{206}$ Slaughter characterizes conflict of laws and choice of law in this situation of basic convergence of liberal values as a "reciprocal dialogue in which courts of different States engaged in a common

203 Tolofson, supra note $\mathbf{1}$ at 1059.

${ }^{204}$ Morguard, supra note 1.

${ }^{205}$ The concept of the liberal peace is taken from I. Kant, "Perpetual Peace," in T. Humphrey, ed., Perpetual Peace and Other Essays (Indianapolis: Hackett Publishing Company, 1983). The modern restatement of the concept as an empirical claim concerning contemporary international relations is found in M. Doyle, "Kant, Liberal Legacies, and Foreign Affairs: Parts One and Two" (1983) 12 Philosophy and Public Affairs 205 and 325 . See also B. Russett, Grasping the Democratic Peace: Principles for a Post Cold-War World (Princeton, NJ: Princeton University Press, 1993); A. Moravscik, "Taking Preferences Seriously: A Liberal Theory of International Politics" (1997) $5^{1}$ International Organization $5^{13}$.

${ }^{206}$ Slaughter, supra note $13^{8 .}$ 
endeavor to make transnational relations among individuals more certain and predictable while taking account of multiple State interests." ${ }^{207}$ From this conception, it follows that (1) courts will face fewer constraints on their application of foreign law, (2) within a "zone of legitimate difference," courts will "presume the legitimacy of a wide range of different means to achieve similar ends" and will only refuse to apply a foreign law where "the potentially applicable laws reflect different choices as to which of those values should trump"; 208 and (3) courts will recognize "a common core of political and economic values that will preserve roughly the same boundary between 'political' and 'legal' questions as would exist in domestic cases." ${ }^{209}$ The process of transjudicial dialogue among the courts of liberal states will be reinforced by the "density and velocity of transnational transactions among liberal states," such as trade, which are leading to convergence in the underlying range of state laws. ${ }^{210}$

Convergence is thought to operate with respect to both rules of private international law and underlying substantive laws. For example, the Supreme Court of Canada in Amchem seemed to think it was presumptuous with respect to anti-suit injunctions to assume that a Texas court would not exercise appropriate restraint in its decision of whether to assume jurisdiction. However, both on the face of Texas laws and with respect to the conduct of the Texas court in the particular case, it was clear that the rules of private international law in Texas were very different from the Canadian rules being applied by the Supreme Court of Canada in its decision. In particular, the Canadian forum non conveniens analysis that the court approved in Amchem was specifically not part of the Texas law at that time. ${ }^{211}$

\section{THE RELATIONSHIP AMONG INTERNATIONALIST POLICY VALUES}

Each internationalist policy value has a separate logic and justification. In addition, internationalist policy values are often presented and understood as providing reinforcing, mutual support for the same kinds of reforms. For example, reforms that promote

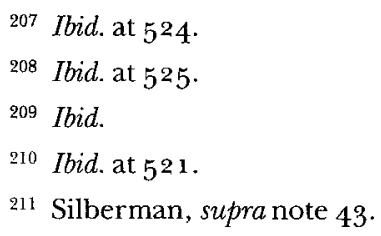


common and uniform rules are defended as aiding economic efficiency through increasing certainty and predictability, promoting cooperative behaviour through limits on strategic manipulation by different jurisdictions, and achieving cosmopolitan fairness by avoiding parochial application of local rules and standards. The sense of reciprocal support among goals as general as commerce, cooperation, and cosmopolitanism, however, permits two kinds of bootstrapping.

First, internationalist reforms are often presented as an overall package, which is then justified as the best available overall package of reforms. For example, reforms intended to strengthen the protection of contractual enforcement are lumped together with reforms geared to controlling the de novo review of recognition and enforcement of judgments, as if these two reforms were necessary to each other.

Second, reforms that are not fully sustainable under one of the policy goals are given additional, incremental support through the belief that they are at least partly consistent with the other policy goals. The linkage of economic arguments for free trade to arguments concerning the cosmopolitan case for free trade has a particularly strong rhetorical effect. The rhetoric of non-discrimination is central to the trade disciplines of the World Trade Organization (WTO) and the General Agreement on Tariffs and Trade (GATT), including, for example, the most-favoured-nation principle (non-discrimination among different trading partners) and the national treatment principle (non-discrimination between foreign and domestic parties). ${ }^{212}$ Free traders often wrap the arguments for free movement of goods into a general claim that only this position is consistent with a moral cosmopolitanism that does not discriminate against foreigners. ${ }^{213}$ It has been argued earlier in this article

212 For example, Articles I and III of the General Agreement on Tariffs and Trade, October 30, 1947, 55 U.N.T.S 194, T.I.A.S. No. 1700 [hereinafter GATT]

${ }^{213}$ See, for example, Trebilcock, supra note 181 at c. 9 . In that chapter, Trebilcock groups together as "discrimination," human rights discrimination, immigration policy, and restrictions on free trade. The connection between liberal attitudes towards free trade and to migration are also evoked in M. Trebilcock and R. Howse, The Regulation of International Trade, 2nd ed. (London: Routledge, 1999) at 1, 13, and 14. There are, however, arguably as many differences as similarities between these topics from a discrimination perspective. For example, the "discrimination" contained in trade restrictions often has less serious consequences for disadvantaged groups and such restrictions are also often justifiable in a way that the other kinds of discrimination are not. 
that this connection is questionable if moral cosmopolitanism is properly distinguished from institutional or legal cosmopolitanism. ${ }^{214}$ More generally, this approach fails to acknowledge that the three internationalist policy goals often do not each provide support for a particular internationalist reform. Indeed, sometimes the three internationalist goals can be in tension with each other. The examination of internationalist public policy values at high levels of generality and abstraction obscures the lack of mutual support and potential conflicts among the three values.

The linkage among international commerce, international cooperation, and cosmopolitanism has deep foundations in traditions of international liberalism. For example, the belief in the "civilizing" force of commerce on international affairs was an important part of liberal arguments for the virtues of a capitalist economic system. In early versions of this hypothesis, a growth in international commerce would create a sense of "interests" that would overcome irrational dynastic and imperial "passions."215 Later British liberals, such as Jeremy Bentham, John Stuart Mill, Richard Cobden, and Norman Angell, argued that free trade would assist peace in a number of ways, including through a recognition that national economic self-interest was not served by military conflict and through the creation of a transnational class of cooperative interests whose self-interests would demand international peace. ${ }^{216}$ In turn, webs of economic self-interest should reinforce the inclination against wasteful international political conflict. ${ }^{217}$ Such

${ }^{214}$ See the section entitled "Cosmopolitanism and Anti-Parochialism" earlier in this article.

215 See A.O. Hirschman, The Passions and the Interests: Political Arguments for Capitalism before Its Triumph (Princeton, NJ: Princeton University Press, 1977) at 79-82. Hirschman is mainly concerned with seventeenth- and eighteenth-century writers, such as Montesquieu and James Steuart. The idea of the doux commerce as a civilizing function continued on in liberal writings on international trade. For example, Mill ends his influential chapter on international trade with the observation that "the economical advantages of commerce are surpassed in importance by those of its effects which are intellectual and moral"; Mill, supra note 140 at $5^{81-82}$.

${ }^{216}$ Joseph Nye labels these two categories of liberal internationalists as "commercial/trade" liberals and "sociological/transnational" liberals; see J. Nye, "Neorealism and Neoliberalism" (1988) 40 World Politics 235 at 245-47. More generally, see M. Ceadel, Thinking about Peace and War (Oxford: Oxford University Press, 1989) especially chapters 6 and 7 .

${ }^{217}$ See, for example, R. Cobden, Russia, 1836 , in R. Cobden, Political Writings of Richard Cobden (London: Unwin, 1903) 122 at 222-25. 
historical conceptions of the interlocking importance of commerce, peace, and cosmopolitanism reinforce the sense that policy reforms directed towards any one of these objectives are also supported by the other policy objectives.

The grouping together of internationalist reform proposals as one overall package and the lumping together of the three internationalist policy goals to provide one overall justification of the reform package obscures careful consideration of internationalist reforms. Internationalist reform in private international law and more generally should not be understood simply as a package deal. Both the set of internationalist reforms and the package of internationalist policy justifications for such reform need to be disaggregated.

\section{Part 5: The Hazards of NaIve Internationalism}

As with many dramatic reforms, the Supreme Court of Canada's general approach to international issues and its application in private international law has limits and dangers. Two general kinds of problems with policy argumentation - false necessity and excluded objectives - also characterize the internationalist policy argumentation in the tetralogy. These concerns do not invalidate the kinds of policy concerns identified in the tetralogy, but they do complicate the policy analysis or reform prescriptions. The result is that rarely are there simple, general prescriptions that apply across fact situations without regard to particular circumstances. This section of the article will identify several kinds of complicating considerations for the international analysis of reform in private international law.

\section{THE APPEAL OF THE COOPERATIVE VISION}

I have described the power of policy justification in international affairs based on consent and cooperative benefit elsewhere. ${ }^{218}$ The specific idea of building an international order that would ensure cooperation rather than conflict is central to the project of public international law. Somehow, through the right combination of laws and institutions, an international order can be achieved that will ensure that the potential harmony of interests among states will be realized. Modern western international law was to play a role 
analogous to that of law in the domestic context - to resolve conflicts among sovereign equals and to realize cooperative benefits. ${ }^{219}$

The ideal of cooperative benefit accords with popular welfare criteria in economics and in international relations. Internationalist law reform is argued to satisfy Pareto optimality in that such reforms make no party any worse off than it was before the reform. ${ }^{220}$ Similarly, game theoretic models of international behaviour suggest that in some situations positive-sum gains to both sides are possible through cooperation. ${ }^{221}$

In international relations, the emphasis on cooperative benefit is especially important because it offers a normative stance that suggests potentially beneficial controls on state sovereignty, without requiring sacrifice by any state that would render such reform proposals seemingly unrealistic. This is especially important in international law because, as Martti Koskenniemi has argued, international law argumentation operates in the difficult terrain between apology and utopia. ${ }^{222}$ International law discourse must constantly straddle between the realistic condition of an international system without a supranational sovereign entity and normative requirements to control sovereign behaviour in the name of global justice and order.

While the focus on inter-jurisdictional cooperative benefit seems convincing in realms such as the laws of war, there are clearly limits to what can be addressed and resolved under this rubric. The welfare criterion of cooperative benefit has the drawback of being unable to address more generally issues of distributive fairness. For example, baseline distributions between parties are not questioned nor are the relative shares of cooperative gains. Cooperative benefit brackets some of the most pressing problems by not taking on difficult issues of distributive justice, regulation, and human rights. ${ }^{223}$

219 M. Koskenniemi, From Apology to Utopia: The Structure of International Legal Argument (Helsinki: Finnish Lawyers' Publishing Company, 1989) at 55-73. Koskenniemi considers the view of the Westphalian Peace as a form of "social contract" in which the liberal structure of politics was adopted into international relations in Europe (at 73).

${ }^{220}$ On the Pareto criteria in welfare economics, see, for example, Trebilcock, supra note 181 at $7-8$.

${ }^{221}$ For a survey of rational cooperation models and international law, see D. Snidal, "Political Economy and International Institutions" (1996) 16 Int'l Rev. L. and Econ. 121.

${ }^{222}$ Koskenniemi, supra note 219.

${ }^{223}$ See Wai, supra note 169 at $235-39$ (limits on arguments from cooperative benefit). 


\section{TWO KINDS OF ERRORS}

Partially because of the powerful pull of the cooperative internationalist vision, there is a danger in the tetralogy of a kind of naive internationalism. Internationalism is too often misunderstood as a single coherent position. Although internationalist policy objectives such as facilitating international commerce or interstate cooperation are worthwhile goals, there are identifiable gaps between the policy objectives and particular legal consequences in any particular subject of private international law. In addition, these policy objectives do not exhaust the range of policy concerns that seem consistent with an internationalist or cosmopolitan viewpoint in private international law.

\section{False Necessity}

The first kind of critique made in dealing with each of the arguments from commerce, cooperation, and cosmopolitanism focuses on the gap that exists between such general policy objectives and the particular institutional or doctrinal reforms that have been advocated. ${ }^{224}$ Inattention to the gap between general internationalist policy goals and particular legal reforms also obscures the possibility that arguments for commerce, cooperation, and cosmopolitanism may be in conflict with each other rather than being mutually supportive, as advocates of internationalist reform in private international law tend to assume.

For example, the goal of promoting international cooperation, with its ideal of cooperation for mutual benefit, is not that useful to private international law because most of the key issues in private international law involve situations of what Joseph Singer has

224 This, of course, is a version of the Holmesian dictum from Lochnerv. New York, 198 U.S. 45 at 76 (1905), Holmes J., dissenting, that " $[\mathrm{g}]$ eneral propositions do not decide concrete cases." This general critique of formalist legal reasoning was a key plank of legal realism. Here, I follow critical legal studies scholars in applying the dictum to policy reasoning in law; see, for example, D. Kennedy, "Form and Substance in Private Law Adjudication" (1976) 89 Harv. L. Rev. 1685; D. Kennedy, "A Semiotics of Legal Argumentation" (1991) 42 Syracuse L. Rev. 75; M. Kelman, A Guide to Critical Legal Studies (Cambridge, MA: Harvard University Press, 1987), c. 4 and 5; J. Singer, "Legal Realism Now" (1988) $7^{6}$ Cal. L. Rev. 465 . For the development of this theme more generally in social theory, see R. Unger, False Necessity (London: Verso, 1987). 
labeled "real conflicts,"225 or what economists would view as situations of choice among Pareto-optimal alternatives. ${ }^{226}$

Similarly, the ideal of cosmopolitan fairness may be convincing as a general frame for reasoning and judgment in private international law, but the ethical ideal of cosmopolitan justice differs from, and cannot justify incontrovertibly, an internationalist institutional orientation. It seems clear that moral cosmopolitanism would reject rules that absolutely refused enforcement of foreign judgments or that always favoured the forum on questions of jurisdiction or choice of law. However, forum-oriented rules can actually favour foreign interests, for example, when foreign laws or processes are disadvantageous to foreign plaintiffs, or where a domestic plaintiff seeks to enforce a foreign judgment against the domestic assets of a foreign defendant. What would a cosmopolitan perspective demand where a court must consider whether to decline jurisdiction over a tort claim by a foreign plaintiff against a domestic business defendant? From one view, anti-parochialism would seem to require that a domestic court should not presumptuously take jurisdiction in a belief that it offers better legal process than a foreign jurisdiction. In this connection, cosmopolitanism would demand that assumptions concerning the inferiority, inadequacy, or absence of foreign laws and processes be carefully examined. ${ }^{227}$ From another view, however, cosmopolitan concern and anti-protectionism suggests that the court should take jurisdiction given that it is a foreign plaintiff who has chosen to make the claim against a domestic defendant, especially where there are weaknesses in the foreign jurisdiction's ability or willingness to protect that plaintiff's interests.

Again, the supposed connection between the goal of promoting international commerce and particular policies, such as rules promoting certainty and predictability, may be contingent on specific fact configurations. The indeterminacy of policy recommendations based on efficiency criteria is often underestimated in

${ }^{225}$ J. Singer, "Real Conflicts" (1989) 69 Boston Univ. L. Rev. 1.

${ }^{226}$ See, for example, G. Calabresi, "Pointlessness of Pareto: Carrying Coase Further" (1991) 1 oo Yale L. J. 1211 ; D. Snidal, "International Political Economy Approaches to International Institutions," in Bhandari and Sykes, supra note 166 at 485 .

${ }^{227}$ A danger especially with respect to developing countries; see, for example, $M$. Sornarajah, "The Myth of International Contract Law" (1981) J. World Trade 187 at $200-01$. 
internationalist reform in law. ${ }^{228}$ For example, international exchange may not be served by instituting clear and predictable rules concerning jurisdiction and the recognition and enforcement of judgments. What efficiency advocates of clear and predictable rules fail to consider is that greater enforcement may be a disincentive for some international transactions. Ex post, it is clear, for example, that a party that is being sued for breach of contract does not consider greater recognition and enforcement to be in its interest. As Duncan Kennedy and Frank Michelman observe in the case of enforcement of contract, "as of the time of the lawsuit, the enforcement of a contract cannot be said to make both parties better off. If performance was in the interest of both parties it would normally occur without enforcement." 229 An analysis based on transaction costs might hold that from an ex ante viewpoint both sides would favour a regime that ensures clear and credible commitments. However, the ex ante appeal of a regime of clear and predictable enforcement might very much depend on what each party believes the future will hold, in particular, whether the party is the promisor or the promisee on a commitment and what the likelihood of breach of the promise is. ${ }^{230}$ In some situations, strict enforcement and clear rules may actually deter transactions.

\section{Excluded International Objectives}

In addition to false necessity with respect to particular legal reforms, a second general problem with internationalist policy reasoning is that concerns about commerce, interstate cooperation, and cosmopolitan fairness do not capture the full range of defensible international objectives. For example, despite the enthusiastic

${ }^{228}$ In Bank of Nova Scotiav. Angelica Whitewear Ltd., [1987] i S.C.R. 59, the Supreme Court of Canada signalled its awareness of this problem in an international commercial context involving letters of credit. Justice Le Dain for the court considered whether the use of letters of credit as an important payment mechanism in international commerce would be advanced by expanding or restricting the fraud exception to a bank's obligation to pay under a letter of credit. Justice Le Dain described how, on the one hand, the international commercial use of letters of credit would be harmed by a broad fraud exception that "created serious uncertainty and lack of confidence in the operation of letter of credit operations," but that, on the other hand, the principle of autonomy of the letter of credit should not be used to "encourage or facilitate fraud" in international transactions (at 72 ).

229 D. Kennedy and F. Michelman, "Are Contract and Property Efficient?" (1980) 8 Hofstra L. Rev. 711 at 741 . 
support for facilitating international commerce in Morguard, the question of whether commerce should be promoted and in what form can be queried for defensible cosmopolitan as well as for domestic reasons. These reasons include considerations of distribution, environmental degradation, and regulatory control. ${ }^{231}$ Moreover, in some contexts, the cosmopolitan or internationalist position may embrace local control and diversity of domestic regimes. In the international realm, a commitment to simple international cooperation or to facilitating commerce may not be possible where real conflicts exist in values and interests among states and among sub-state and transnational interests.

Similarly, the goals of facilitating international commerce and interstate cooperation suffer from various limits related to their economistic reasoning. These problems include a state-centric focus, an under appreciation of non-economic interests, and the difficulty of defining interests where there are substantial transnational connections and identities. ${ }^{232}$ Once broader conceptions of interest are used, the reform implications of internationalization for doctrinal reform become complex and particularistic.

\section{SIX DANGERS IN THINKING ABOUT THE INTERNATIONAL}

A sophisticated understanding of the international requires recognition of complexity. The international rarely simplifies; it usually adds complexity to analysis. Arguably the Supreme Court of Canada was engaged, in the tetralogy, in a sophisticated area-byarea focus on reforms informed by, but not overwhelmed by, its internationalist vision. However, a naive interpretation of the judgments may lead lower courts and some commentators to incorrectly conclude that there is a single internationalist policy that can be routinely or automatically applied to dispose of individual cases. ${ }^{233}$ The next section describes several kinds of errors that seem to result from the failure to recognize that many internationalist policies do not lead to obvious particular reforms and that there are a number of different kinds of policy objectives, all of which are international in their orientation.

${ }^{231}$ I elaborate on the goal of transnational regulation in private international law in Wai, supra note 168.

${ }^{232}$ See Wai, supra note 169 at $236-39$.

${ }^{233}$ It may be that the expansive application of Morguard, supra note 1, to recognition and enforcement of default judgments from non-Canadian jurisdictions may be an example of this kind of misperception; see Blom, supra note 28 . 


\section{International Relations IOI: The Consequences of Anarchy}

The theme of comity among courts and among societies is invoked repeatedly in the court's judgments in the tetralogy, as in its judgments in other areas of law related to international matters, such as criminal law, extradition, and sovereign immunity. ${ }^{234}$ Informing the principle of comity is the idea that national courts should give proper respect and deference to foreign interests, values, and institutions so as to promote a better international order. Canadian courts should adopt a proper respect for the institutions and interests of foreign jurisdictions in order to encourage cooperative behaviour more generally in the international system. In addition, the presumptively shared benefits of greater efficiency in dispute resolution require that deference be shown to foreign courts and to the choices of parties with respect to forum selection, arbitration, and choice of law.

From an international relations perspective, however, this view ignores the basic structure of an anarchic international system: the lack of an overarching authority that can ensure compliance and reciprocity on the part of individual participants in that system. ${ }^{235}$ The game theory models described earlier have as their descriptive purpose an explanation of how, even in situations of potential cooperative benefit, it is rational for a state not to cooperate with others given the lack of a compliance mechanism. In some accounts, forms of unilateralism and retaliation are sometimes required in order to get an imperfect form of compliance. In such a realm, one-sided voluntary internationalism may reward the parochialism of others and, perversely, harm the long-run benefits of an international order. ${ }^{236}$ Thus, for example, the willingness of Canadian courts to be restrained in granting anti-suit injunctions, to decline jurisdiction for forum non conveniens, and to recognize and enforce foreign judgments including default judgments may actually encourage jurisdictions such as Texas to refuse to adopt similar restraints. ${ }^{237}$

${ }^{294}$ I discuss these similarities in Wai, supra note 6.

${ }^{235} \mathrm{H}$. Bull, The Anarchical Society (London: Macmillan, 1977).

${ }^{236}$ See, for example, Trebilcock and Howse, supra note 213 at 7-9, for a discussion of this argument in the context of international trade regulation.

${ }^{237}$ Effectively, non-reciprocity means abandonment of a "tit-for-tat" strategy that may actually serve the strategic purpose of achieving a rough form of international cooperation; see Brilmayer, supra note 55 at $184-87$. 
To the extent that it addresses the international anarchy at all, the court in the tetralogy seems to anticipate a strategy of "leading by example" so as to build up trust and reciprocity and to achieve cooperative benefits even without effective international institutions. In addition, it seems to rely on the presence of similar values among foreign adjudicators and legislators, with respect to the laws and principles of private international law such as comity.

This approach is connected to the tendency in the tetralogy to elide the federal and the international levels in policy analysis. It is revealing that three of the cases in the tetralogy involve conflicts among Canadian jurisdictions. In Hunt, indeed, the court specifically excluded consideration of the international aspect. However, the underlying policy logic of the cases, and the nature of the fourth case, Amchem, have suggested to many commentators and lower courts that the same kinds of reforms were required with respect to non-Canadian jurisdictions. For example, a large number of cases have applied Morguard to the recognition and enforcement of judgments from non-Canadian jurisdictions, predominantly from the United States. ${ }^{238}$ The principle of comity, which is seen to be central to Morguard and the other cases, has also led courts to creatively change other doctrines, such as easing the rule against enforcement of foreign public laws. ${ }^{239}$

There are several difficulties with too closely analogizing international relations and federal systems. Most serious is that there are substantial and fundamental differences in the political and legal contexts of international and federal systems. Most obviously, without an effective international convention, Canadian courts have limited ability to directly control or reliably predict the behaviour of foreign courts or legislatures. In the Canadian federal context, in contrast, the Supreme Court of Canada, the federal government, and the other political institutions of the federation permit some direct control. Therefore, it seems foolish to simply analogize interprovincial and international disputes in the context of controlling aggressive assumptions of jurisdiction by foreign courts, part of

238 Some lower courts have applied Morguard to international cases of recognition and enforcement; see, for example, Moses v. Shore Boat Builders Ltd. (1993), [1994] 106 D.L.R. (4th) 654 (B.C.C.A.), leave to appeal to S.C.C. refused, [1994] i S.C.R. xi [hereinafter Moses]; Arrowmaster Incorporated v. Unique Forming Ltd. (1993) 17 O.R. (3d) 407 (Gen.Div.). See, generally, Blom, supra note 28; Sullivan, supra note 16 .

${ }^{239}$ For example, United States v. Ivey, (1995) 26 O.R. (3d) 533 at 549 , citing the principle of comity from Morguard in support of reform of the rule. 
the function of both restrictions on recognition and enforcement of judgments as in Morguard and anti-suit injunctions as in Amchem. A basic understanding of international relations would highlight this point. In the absence of any overarching authority, there is only an indirect hope for comity and reciprocal restraint by foreign jurisdictions.

Furthermore, the assumptions about convergence in values among different jurisdictions that inform the tetralogy and that are most evident in the Tolofson judgment may apply very differently within the Canadian federation as compared to between Canadian and foreign jurisdictions. A liberal theory of international relations might argue that a private international law among liberal jurisdictions should be much more harmonious and comitious because the underlying values represented in both the substance and processes of law should be similar. ${ }^{240}$ This assumption, however, is less than determinative for the purposes of private international law. Convergence on some basic political values does not obviously or necessarily translate into greater convergence in legal regimes nor greater accommodation in practice. After all, many conflict of laws disputes are generated by disputes between Canadian provinces, which share nearly identical liberal political values, and yet legal differences that matter to private law disputes continue, as in the differences over the passenger laws of Saskatchewan and British Columbia in the Tolofson case. The divergences are still greater with many of our liberal neighbours in the United States the source of most of the private international law disputes that Canadian courts will face. Significant differences in societal values and legal rules exist between Canadian and US jurisdictions on major issues such as gun control, affirmative action, and the death penalty. ${ }^{241}$ These differences extend to private law and private procedure, especially in so far as private law performs functions of social regulation. The final part of this article contains a more

${ }^{240}$ Slaughter, supra note 138 .

${ }^{241}$ In this connection, it is interesting in this respect to compare the majority Supreme Court of Canada judgments with respect to extradition to the United States to face the potential death penalties in Kindler, supra note 118 , and $R e N g$ Extradition, supra note 118 , which were written by a court contemporaneously generating the tetralogy in private international law. In contrast, the recent judgment in United States v. Burns, supra note 119 , may indicate a rethinking at the court concerning the nature of its internationalism in the criminal law area. For an argument concerning some of the shared characteristics of the extradition cases and the tetralogy in private international law, see Wai, supra note 6 . 
extended discussion of this concern using the example of punitive damages.

\section{Real Conflicts and the Sacrifice of Domestic State Interests}

A weak appreciation of the consequences for cooperation of a fundamentally different structure of an international anarchy is worsened when an internationalist approach fails to appreciate that significant jurisdictional interests may sometimes be at stake in private litigation across borders. For example, a policy of comity with respect to foreign state processes and laws is a potential problem if domestic interests are too readily sacrificed. While the US governmental-interest analysis of choice of law problems may often overstate the state legislative interest in private law disputes, there are occasions when a state's interests in having the level of regulatory protection of, for example, its tort laws could be jeopardized by deference to a foreign court's assumption of jurisdiction or through a decision to apply foreign law rather than forum law. This is especially a concern if regulatory preferences are understood to include not only the decision to set a high standard of regulatory protection but also to set a lower standard based on balancing a number of different interests and policies. ${ }^{242}$ Comity in this situation may undermine the complex political and normative settlements that underpin the regulatory structure of a Canadian jurisdiction.

The Hunt decision evidences the manner in which private international law disputes may raise issues that are of significant legislative and social concern. The Québec blocking statute, which was held to be inapplicable, was legislation that specifically identified out-of-province and outside-of-Canada asbestos litigation as being problematic for the public policy of Québec. With respect to this issue, the Québec National Assembly presumably was concerned with a range of interests, including those of the workers in the Québec asbestos industry. To prioritize international system objectives, such as the promotion of international trade or the cosmopolitan fairness to litigants, is to overturn this legislative determination.

Similarly, the liberal recognition and enforcement of foreign judgments rendered against Canadian defendants might constitute a significant additional cost for Canadian businesses. This is a problem if the assessment of the quality of the connection of the foreign

242 Singer, supra note 225 at 41 . 
court to the dispute is too deferential. Moreover, since comity and cooperation, not reciprocity or a binding international treaty, are the guiding principles, there is no way to ensure that the foreign jurisdictions are treating Canadian judgments in the same way. Similar concerns exist with respect to the policy set out in Amchem of discouraging the use of anti-suit injunctions.

\section{Unfairness to Individuals}

A further concern about the internationalist approach in the tetralogy is that in adopting an international focus, the court both overstated the importance of private international law to interstate cooperation and understated the importance of private international law to individual parties. The consequence is an approach that departs from the traditional focus of Canadian private international law on fairness to the parties and moves instead towards the protection of systemic goals such as ensuring cooperative interstate order and facilitating interstate commerce.

Traditional private international law in Canada, in contrast to US governmental-interest analysis, has not emphasized the significance to state interests of most kinds of private international law disputes. Private international legal disputes are often relatively minor from the point of view of states, and military conflict or trade wars are not real consequences of private international law disputes. As Max Rheinstein notes, " $[\mathrm{n}]$ ever in private law is there a conflict between states in the sense in which states clash on questions of boundary, treatment of foreign nationals or property, or spheres of interest." 43 One view would be, therefore, that the court's internationalist approach is a sensible trade-off of some limited state interests for the benefits of encouraging the state interests in international order, international commerce, and anti-parochialism.

This emphasis on international system concerns and objectives would not be a problem if state interests were the only matter at hand. Private international law in the Commonwealth traditions, however, has traditionally focused on the conflicts between the interests and preferences of individual parties. A significant danger in promoting international system objectives is that the interests and values of individual parties are dealt with unfairly. This concern about the consequences of focusing away from individuals

${ }^{243}$ M. Rheinstein, "How to Review a Festschrift" (1962) 1 1 Am. J. Comp. L. 632 at 664, quoted in F. Juenger, Choice of Law and Multistate Justice (Boston: Martinus Nijhoff, 1993) at 161, n. 997 . 
and onto states is what has undermined English support for the doctrine of comity. ${ }^{244}$ Before the tetralogy, Canadian courts followed the English courts in de-emphasizing state interests and attempting to develop private international law rules based on the characteristics of different categories of relations among individual litigants.

The sacrifice of individual fairness is a major problem in a liberal interpretation of the rules from the tetralogy. Generous and liberal recognition and enforcement of foreign judgments may assist in predictability and in interstate relations, but it may be unfair to a defendant who has formulated expectations of justice based on its various connections to a Canadian jurisdiction and a foreign jurisdiction. Similarly, the use of a rigid lex loci delicti rule assists in promoting predictability and in protecting against parochialism in choice of law in tort. However, the unfairness to individual litigants can be very high, and it can be argued that in Tolofson, Justice La Forest and the court may have become too focused on systemic objectives at the cost of fairness to the plaintiffs whose substantive claim failed because of the ruling. The idea that as between order and fairness "order comes first" ${ }^{245}$ is to overstate the importance of certainty to order and the importance of order itself. Some degree of conflict can be managed in transnational civil litigation without serious losses to the system; in comparison, unfairness to individuals caused by false suppression of conflict can be substantial. It is for this reason that Jean-Gabriel Castel, reasserting the values of the traditional private international law approach, argues that "[i]f a choice must be made, fairness should prevail over order." 246

\section{Disturbing the Laws and Politics of Federalism}

I noted earlier that the tetralogy evidences a strong and dangerous tendency to analogize the international to the federal, even

244 See Dicey $\mathcal{E}^{2}$ Morris, supra note $9^{2}$ at $5^{-6}$ :

[I]t is clear that English courts apply e.g. French law in order to do justice between the parties, and not from any desire to show courtesy to the French Republic, nor even in the hope that if English courts apply French law in appropriate cases, French courts will be encouraged in appropriate cases to apply English law.

The authors' choice of France for their example is of interest.

245 Tolofson, supra note 1 at 1058 .

${ }^{246}$ Castel, supra note 10 at 67 . 
where the basic institutional features of the two levels are different. There is a further danger connected with too closely identifying the international and the federal in policy reasoning: the disturbance of established and functioning federal systems of governance. The tetralogy demonstrates a fascinating connection between changing international realities and issues of Canadian federalism. Justice La Forest, for example, the leading judge at the court in the tetralogy and in international law more generally, was also a leading expert on federalism, both as an academic ${ }^{247}$ and as a judge. ${ }^{248}$ The tetralogy - particularly its ideas about the constitutional limits on provincial jurisdiction, the Canadian common market, and the significance of mobility rights - provides a powerful vision of a federation in need of reform to suit both Canadian and international realities. ${ }^{249}$ At the policy level, the tetralogy emphasizes the close connection between federal and international analyses in that the Supreme Court of Canada and lower courts have almost interchangeably identified a process of increasing commerce, mobility, and convergence in values in both federal and international societies and argued for similar legal responses in both venues. The potential hazards of reforms to federalism posed by the tetralogy have been somewhat obscured because the effective mode of internationalization has been by policy consciousness rather than by formal implementation of international treaties.

Internationalization through the mode of international treaties can pose serious challenges for the division of powers in federal states. In the law and politics of Canadian federalism, the federal treaty implementation power has been a frequent source of contention between those who advocate the need for a federal state to act in a unified way on the international plane and those who believe that an expansive federal treaty implementation power

${ }^{247}$ G.V. La Forest, The Allocation of the Taxing Power under the Canadian Constitution, 2nd ed. (Toronto: Canadian Tax Foundation, 1981); G.V. La Forest, Natural Resources and Public Property under the Canadian Constitution (Toronto: University of Toronto Press, I 969 ). In an early article, Justice La Forest made the connection between the constitutional law of federalism and international law; G.V. La Forest, "May the Provinces Legislate in Violation of International Law?" ( 1961 ) 39 Can. Bar Rev. 78 .

${ }^{248}$ See, for example, $R$.v. Crown Zellerbach Canada Ltd., [1988] i S.C.R. 401, La Forest J. dissenting; Air Canada v. B.C., [1989] 1 S.C.R. 1161; Friends of the Oldman River Society v. Canada, [1992] i S.C.R. 3; Ontario Hydro v. Ontario (Labour Relations), [ 1993 ] 3 S.C.R. 327 .

249 See McEvoy, supra note 23. 
effectively undermines provincial powers. ${ }^{250}$ More recently, international trade treaties, such as the WTO agreements ${ }^{251}$ and the North American Free Trade Agreement (NAFTA), ${ }^{252}$ create complex issues related to the law and politics of federal states. ${ }^{253}$ The tetralogy never directly addresses the issue of the treaty implementation power, but the judgments do effectively constrain provincial jurisdiction since most private law and, consequently, most private international law is within provincial jurisdiction. In Morguard, the court found constraints on courts applying provincial common law with respect to the recognition and enforcement of judgments from other provinces; lower courts have extended this reasoning to judgments from non-Canadian jurisdictions. In Hunt, the court prevented provincial legislatures from impeding trans-provincial litigation by constitutionalizing certain limits on provincial jurisdiction in the area of private international law. The court did not elaborate on these limits and expressly did not rule on whether there are any limits on provincial legislatures on private international law matters with respect to non-Canadian jurisdictions, ${ }^{254}$ but it seems clear that this decision amounts to a constitutional limit on provincial legislative jurisdiction, which had not formerly been articulated and which has almost as much impact as the implementation of a formal international treaty. ${ }^{255}$

250 A.G. Can. v. A.G. Ont. (Labour Conventions), [1937] A.C. 326. For the debates about the treaty implementation power, see Hogg, supra note 115 at C. 11; G.V. La Forest and Associates, Water Law in Canada: The Atlantic Provinces (Ottawa: Information Canada, 1973) at 63-68.

251 For example, GATT, supra note 212 at Article XXIV(12).

252 NAFTA, supra note 187.

${ }^{253}$ See, for example, D. Wirth, "Government by Trade Agreement," in D. Dallmeyer, ed., Joining Together, Standing Apart: National Identities after NAFTA (The Hague: Kluwer, 1997) 111 at 1 24-25. The impact of international trade treaties on not only issues of federal-state relations but also municipal government is demonstrated clearly by the recent arbitral award of the tribunal constituted pursuant to Chapter 11 of the NAFTA in Metalclad Corp. v. Mexico (Arbitration Award, August 30, 2000) and the judicial review of that award, Mexico v. Metalclad Corp., [2001] B.C.J. 950 (BC Supreme Court, May 2, 2001).

254 Hunt, supra note 1.

255 Another example of the indirect impact of internationalization on federal relations is seen in the recent decision of the Supreme Court of Canada in Ward v. Canada (Attorney General), 2002 S.C.C. 17 , where the court considered whether federal legislation restricting the trade in seal and seal products fell within the federal fisheries power under section 91(12) of the Constitution Act, 1867 , supra note $\mathbf{2 4}$, or fell instead within provincial powers over property and civil 
There are several points to make about these increased constraints placed on provincial legislatures and courts. First, many of the other concerns about the reforms in the name of the international also apply with respect to reforms done in the name of the federal in an era of the international. There are significant differences between the two levels; for example, the federal government and the Supreme Court of Canada have an oversight role that differs from the formally anarchic relations between sovereign states. However, as with the international context, there remain significant differences in social and legal values among provinces, provincial laws often reflect policy compromises developed to suit local communities, and reform to suit federal relations may overlook fairness to individuals whose expectations may be linked to provincial laws and processes.

Second, it is important to remember the central concern of the difficult debate over the treaty implementation power, which is that merely because a matter has international dimensions does not mean that legislative jurisdiction should be automatically removed from the local levels of government. Within Europe, the debates about subsidiarity have emphasized the costs associated with removing policy-making to higher and more distant levels of government. This lesson, of course, is a major theme of the Canadian constitutional law on the federal division of powers.

Finally, the rules that should apply to the conflict of laws among Canadian jurisdictions might be different from the rules that should apply with respect to non-Canadian jurisdictions. It seems clear that Canadian jurisdictions should be careful in simply extending the same treatment given to other Canadian jurisdictions to foreign jurisdictions under principles such as those provided in Morguard. Still more clearly, the unanswered question in Hunt, concerning whether there are constitutional limitations on the power of provincial legislatures with respect to non-Canadian jurisdictions, should be answered so as to permit provincial legislatures significant room to choose their private international law rules with respect to non-Canadian jurisdictions. This flexibility

rights under section 92 (13). In characterizing the legislation, the court referred to the desire of the federal government to respond to concerns about international sales boycotts of seal and other fisheries products as relevant to its characterization of the federal legislation as being in pith and substance concerned with matters of management and control of the fisheries. Ibid. at paras. 2,8 , and 21 . 
concerning constitutional limits is needed to temper the existing effects of internationalist reform on the federal division of powers, to account for the problem of oversight and divergence in values with non-Canadian jurisdictions, and for reasons of deference to legislatures in international matters - a matter that will be discussed in the next section.

\section{Constitutionalization and Legislatures, Executives, and the Courts}

As was noted earlier, the lack of an effective overarching institutional authority in international matters means that real conflicts develop between sovereign entities that cannot be resolved in a determinative fashion. Instead, many international disputes are resolved, if at all, through extended processes of international negotiation and compromise. ${ }^{256}$ While similar kinds of enforcement difficulties arise in domestic disputes, there are still substantial differences in degree between the two contexts.

An awareness of workable political process in international relations requires an awareness of the relative strengths and drawbacks of various institutional alternatives. National courts without enforcement power outside their jurisdiction are usually not the best political institutions for dealing with international conflict. For example, national courts are neither authorized nor able to directly negotiate with foreign jurisdictions, to engage in ongoing negotiation and monitoring, to link issues to create the possibility of larger compromises, and to engage in broader consultations with affected domestic constituencies as negotiations proceed. All of these arguments are familiar policy concerns, which inform the traditional deference of common law courts to the executive branch on international matters, which is evident in doctrines such as sovereign immunity ${ }^{257}$ and in the Crown prerogative to conduct international relations. ${ }^{258}$

${ }^{256}$ Even within the more "legalistic" processes established in international institutions such as the WTO, dispute resolution retains significant "pragmatic" elements; see, generally, G. R. Shell, "Trade Legalism and International Relations Theory: An Analysis of the World Trade Organization" (1995) 44 Duke L. J. 829 .

257 See S. Williams and A.L.C. de Mestral, An Introduction to International Law: Chiefly as Interpreted and Applied in Canada, and ed. (Toronto: Butterworths, 1987) c. 8.

${ }^{258}$ See Hogg, supra note 115 at sections $1.8,11.2$, and 11.3 . 
In the tetralogy, the court seems to move away from this deference in the realm of private international law. In this respect, Canadian courts should take a lesson from Justice La Forest's work in other areas, which emphasizes the limits of national courts as an effective institution in the international context. ${ }^{259}$ This sense of limits of national courts has led him to argue, for example, for deference to the executive and legislative branches in the application of the Charter in almost all international matters. First, some Charter rights were modified for the international context. For example, Justice La Forest emphasized that the scope of Charter review does not extend to the review of foreign proceedings for problems such as unreasonable delay or inadequate counsel. ${ }^{260} \mathrm{Sec}-$ ond, Justice La Forest's approach to the justification of infringement under section $\mathbf{l}$ of the Charter gave significant discretion to the political and executive branches of the Canadian government to take into account the numerous considerations that might be at play in legal disputes with an international aspect. ${ }^{261}$

The deferential approach adopted by Justice La Forest in the Charter context seems to contrast sharply with the constitutional limits on provincial courts and legislatures in private international law articulated in the tetralogy. Particularly in the Hunt decision, Justice La Forest seemed to signal that the room for provincial legislatures to set private international law rules that are not in keeping with the basic norms of comity will be tightly controlled. While the degree of deference to the legislative and executive branch in the Charter context might be too statist and deferential on some international matters, such as extradition, the degree of internationalist activism demonstrated in the tetralogy at times seems too interventionist.

It may be that since private international law is an area predominantly developed by common law courts, Justice La Forest was less concerned with the problems of a lack of institutional competence. Given little evidence that legislatures were intending to legislate in

259 In Wai, supra note 6, I compare and contrast the lack of deference in the tetralogy with (1) Justice La Forest's legal realist take on the limited effectiveness of adjudication in comparison to legislative, executive and administrative processes; (2) his generally deferential attitude towards the legislative and executive branches in the application of the Charter; and (3) his restricted idea of the role of national courts in other international areas, such as in extradition.

260 Canadav. Schmidt, supra note 118 ; R.v. Harrer, [1 995] 3 S.C.R. 562.

261 United States v. Cotroni; United States v. El Zein, [1 989] i S.C.R. 1469 at $1487-90$. 
private international law to institute international reforms, it fell to the courts to promote such reform. None of these arguments, however, overcomes the concern that with respect to international reform more recognition is needed of the traditional limits of common law courts in international matters.

This concern is most problematic in the implications of constitutionalization for the ability of provincial courts and legislatures to tailor their reforms to the complex process of policy involving foreign jurisdictions. In some areas, such as in the blocking statute deliberately constructed by the provincial legislature with respect to asbestos litigation in Hunt or in legislation such as clawback statutes in antitrust, it seems clear that the legislative branch has spoken and should be given wide discretion to tailor domestic laws for political exigencies, including extended or failed international negotiations. In light of the institutional disadvantages of the common law courts, it makes some sense to restrictively interpret the constitutionalization of the rules of the tetralogy at least with respect to non-Canadian jurisdictions. In Hunt, for example, the court expressly did not address the issue of whether the blocking statute would be constitutionally inapplicable with respect to litigation proceeding in non-Canadian jurisdictions. Given the different institutional structures, as well as the lack of relative institutional competence of the courts in foreign affairs, ${ }^{262}$ the constitutional limits on provincial legislatures should be less restrictive with respect to non-Canadian jurisdictions than with respect to other Canadian provinces. ${ }^{263}$ In Tolofson, Justice La Forest signalled that the rigid lex loci delicti rule might permit exceptions for "injustice, in certain circumstances," although he thought they would be few. ${ }^{264}$ It may be that significant differences in the underlying tort law and the choice of law rules in tort between Canadian and non-Canadian jurisdictions, including US jurisdictions, might mean that Canadian courts and particularly Canadian legislatures should be permitted to vary the rule.

262 Justice La Forest notes in Hunt, supra note 1 at 328 , that the federal Parliament is expressly permitted by the constitution to legislate with international extraterritorial effect; see Statute of Westminster, I93 I (U.K.), 22 Geo.V, c.4, s. 3: "It is hereby declared and enacted that the Parliament of a Dominion has full power to make laws having extra-territorial operation."

263 Hunt, supra note $\mathbf{1}$ at 331.

264 Tolofson, supra note 1 at 1054 . 


\section{Overlooked International Objectives}

In addition to harms to individual, local, and federal interests and policies, the concern to promote international commerce and interstate relations may lead Canadian courts to ignore other important international objectives, such as effective international regulation or distributive justice across state borders. For example, internationalist reform may overlook the function of private international law in assisting the regulatory oversight of transnational businesses. ${ }^{265}$ Internationalist policy argumentation tends to promote court respect for party autonomy in the choice of disputeresolution by forum selection, choice of law, and arbitration clauses. However, this approach may fail to identify appropriately the regulatory challenges posed by this "lift-off" of transnational business from state-based private law regulation. As in the domestic realm, the courts are part of a complex mix of institutional processes, both governmental and non-governmental. Courts may provide a more accessible point of access for groups or individuals than either legislative or executive processes. In view of the increasing concern that key areas of social control are slipping away into international bureaucracies and global markets, it may be necessary to critically and creatively re-evaluate or limit the institutional deference of national courts to other domestic, foreign, and international institutions.

In the final part of this article, I will attempt to explore how concerns such as effective transnational regulation can be better incorporated into a policy approach to private international law that acknowledges complexity and the existence of plural objectives.

\section{Part 6: Two Examples of Particularistic and Contextual Internationalist Policy Analysis}

It has been argued that considerations of the international rarely simplify, and frequently make more complex, legal determinations in private international law. The response must be that general policy concerns such as international commerce, interstate cooperation, and cosmopolitan fairness identify valuable concerns, but that other international and domestic policy goals must be considered. Particularism and context will therefore matter very much. ${ }^{266}$

265 I argue this in Wai, supra note 168.

${ }^{266}$ For example, in Wai, supra note 169 , I argue that the commercial activity exception to sovereign immunity lacks necessary particularism. This is particularly 
This need not lead to hopelessly fact-specific determinations. The internationalist policy objectives, together with others, help to identify dimensions of concern that will help to structure argumentation and decision in particular cases. ${ }^{267}$ In this respect, private international law already contains complex doctrines such as dépeçage, under which different national laws might apply to different aspects of one relation or transaction. ${ }^{268}$ In a pragmatic or eclectic framework, this principle might extend as well to tailoring applicable laws and procedures for the structural features of different kinds of disputes, such as the nature of the foreign jurisdiction involved in the problem. The ability to address complexity and real conflicts with an orderly framework for argumentation and decision-making is key to private international law. In order to show how this kind of contextual analysis might operate in Canadian private international law, this section concludes the article with some international policy analysis of two contrasting examples: jurisdiction over Canadian corporations conducting business in developing economies, and the recognition and enforcement of US punitive damages awards.

JURISDICTION, FORUM NON CONVENIENS, CANADIAN COURTS, AND CANADIAN CORPORATIONS IN THE DEVELOPING WORLD

In Amchem, the Supreme Court of Canada promoted the use of forum non conveniens as a vehicle for the rational allocation of jurisdiction and the promotion of comity in inter-jurisdictional relations. There are many virtues to the doctrine, and it has been adopted in a number of non-Canadian jurisdictions as well. However, there are also dangers. In particular, there is a danger in considering whether there is forum non conveniens of a lapse into naive internationalism through an excessive concern with comity and procedural efficiency. Such concern with comity and efficiency may be inappropriate in a context where the litigation is directed

problematic when, on the one hand, a broad exception to sovereign immunity has been taken with respect to commercial activity and, on the other hand, the immunity rule has been applied broadly with respect to almost all other kinds of activity, including activity involving human rights abuses.

${ }^{267}$ For a model of this "pragmatic" approach in the US conflict of laws, see J. Singer, "A Pragmatic Guide to Conflicts" (1990) 70 Boston Univ. L. Rev. 731.

${ }^{268}$ Under dépecage, various state laws may govern different aspects of a "single" business relationship, for example, different laws may apply sales, transportation, and credit aspects. See, for example, Rome Convention, supra note $8_{3}$, articles 3 (1) and 4(1); Castel et al., supra note 71 at 171 . 
against a Canadian corporation conducting business abroad in a developing country. In this context, a Canadian court may require a more nuanced sense of $(1)$ the problem of effective transnational regulation where the other potential jurisdictions for the litigation have weak or non-existent regulatory protection and (2) the need to protect justice and fairness for the foreign plaintiff.

A more sophisticated and contextual understanding of the international system would recognize the need to assess differentially jurisdictional issues related to attempts to sue Western multinational enterprises in their home jurisdictions for claims related to their operation abroad in developing economies. Canadian courts that focus narrowly on the convenience of litigation may decline jurisdiction with the consequence of injustice to foreign plaintiffs, under-regulation in the transnational system, and even a form of inadvertent parochialism. In the most prominent example of such a case since the tetralogy, a Québec court used forum non conveniens analysis to grant a stay of proceedings in Québec courts against a Québec-based mining company accused of causing environmental damage in a cyanide spill at one of its mines in Guyana. ${ }^{269}$ The case recalled the decision of the New York courts to decline jurisdiction for reasons of forum non conveniens in litigation by Indian plaintiffs against Union Carbide for the Bhopal chemical factory accident in India. ${ }^{270}$

The Québec court in Recherches Internationales Québec v. Cambior Inc. ${ }^{271}$ seemed especially concerned to emphasize the need for

${ }^{269}$ Recherches Internationales Québec v. Cambior Inc., [1998] Q.J. No. 2554 (Quebec Superior Court, August 14, 1998) [hereinafter Cambior]. For an extended commentary, see S. Seck, "Environmental Harm in Developing Countries Caused by Subsidiaries of Canadian Mining Corporations: The Interface of Public and Private International Law" (1999) 37 Can. Y.B. Int'l L. 139.

${ }^{270}$ Re Union Carbide Corporation Gas Plant Disaster at Bhopal, India in December, 1984 , 634 F. Supp. 842 (S.D.N.Y. 1986), aff'd 809 F.2d 195 (2d Cir. 1987) [hereinafter Union Carbide]. The Second Circuit ruled that a suit against Union Carbide by Indian victims and the Indian government of the Bhopal chemical disaster was forum non conveniens in the New York courts and should be heard in the courts of India. This conclusion was reached in spite of the submissions of the Indian government who agreed that the suit was better heard in the US court. The court did impose a number of conditions on its stay, including that Union Carbide consent to submit to the broad discovery under the US Federal Rules of Civil Procedure. For critical commentary, see U. Baxi, Inconvenient Forum and Convenient Catastrophe: The Bhopal Case (Delhi and Bombay: Indian Law Institute and N.M. Tripathi, 1986); Paul, supra note 145 at 61-2.

${ }^{271}$ Cambior, supra note 269 . 
comity and due respect for the courts of Guyana, focusing on evidence as to the procedural effectiveness of the Guyanese courts. This reinforced the other main concern of its analysis, namely issues of procedural advantage such as proximity to the accident site and to relevant witnesses.

While the relative connections of the action to Québec and Guyana can be debated, the court might have factored in a concern with effective transnational regulation as an international policy objective, which is as important as interstate cooperation and comity or procedural efficiencies. These regulatory concerns arise both at the international level and the domestic level. At the international level, it may be that there are systemic problems of under-regulation of transnational business conduct. With weak international-level regulatory authorities, regulatory gaps with respect to externalities created by transnational business actors often fail to be regulated by an imperfectly coordinated set of sovereign authorities. In some cases, a process of regulatory competition may worsen the regulatory problem as states compete to attract economic production by mobile transnational business actors through reductions of domestic regulatory levels below levels that would otherwise be chosen by those societies. ${ }^{272}$

There may also be substantial reasons for a Canadian court to consider the challenges for developing countries in creating and implementing an effective regime of domestic regulation of business conduct. In the Cambior case, there was little sign that effective environmental regulation was in place. Likewise, the tort laws related to environmental damage were weak and not well suited to the scale of the mining or to the size and resources of the transnational defendant. In contrast, Canadian courts are very familiar with both the public and private law regulation of mining companies and their operations. Moreover, in the surrounding support for such litigation, the Canadian jurisdiction may offer significant advantages, including better support services, better access to experts, and superior non-governmental organization support. This is not to argue that developing economies always lack effective legal systems, only to argue that a court may need to consider more broadly what effectiveness would amount to in a particular litigation. ${ }^{273}$

272 I discuss regulatory gaps and regulatory competition as problems of international cooperation in private international law in Wai, supra note 168 at $25^{0-5} 8$.

${ }^{273}$ The recent House of Lords decision in Lubbe v. Cape plc, [2000] 4 All E.R. 268 (H.L.), considered forum non conveniens, but in its application permitted South 
In both Re Union Carbide Corporation Gas Plant Disaster at Bhopal, India in December, $1984^{274}$ and Cambior, the courts used an internationalist rhetoric of comity where arguably no real issue of comity was present and where substantial policy goals would have been served by the assumption of jurisdiction. In Union Carbide, comity concerns seemed especially improbable given that the Indian government expressly did not object to the assumption of jurisdiction by the New York court over the litigation. In Cambior, the Guyanese government neither objected nor promoted the litigation. ${ }^{275}$ This should not be surprising given that governments may want to appear neutral so as not to alarm current or future foreign investors or to invite more general incursions of foreign courts into other domestic matters. ${ }^{276}$

Policy arguments related to cosmopolitan fairness and antiparochialism in the Cambior case would seem to operate against, rather than for, applying forum non conveniens in this case. It is hard to see how it can be anti-parochial to reject the preferences of foreign plaintiffs and instead observe the preferences of a defendant with strong Canadian connections. Indeed, by declining jurisdiction, the court is open to the accusation that it fed into perceived Canadian economic interests.

Neither do arguments based on individual fairness to the Canadian defendant seem especially strong. Canadian corporations and their legal advisors are familiar with the Canadian legal process even more so than with the processes of a foreign jurisdiction. While such corporations will not necessarily be held to the same standards as at home, they should have some expectation of possible legal challenges based in Canadian courts. Moreover, as assumption of jurisdiction is not the same as choice of law, a Canadian court may still choose to apply the foreign law even after

African plaintiffs to continue with their litigation in English courts against an English parent company for personal injuries related to exposure to asbestos. This decision may be an example of greater sensitivity to the particular procedural problems that may impede litigants in the legal systems of some developing countries.

274 Union Carbide, supra note 270.

${ }^{275}$ Comity concerns make more sense where governments take a position that domestic processes are sufficient.

${ }^{276}$ On the difficult position of developing countries with respect to international legalism in a global context of neoliberalism and neoimperialism, see Wai, supra note 169 at $241-45$. 
assuming jurisdiction. And, in any event, the foreign plaintiff must still overcome the substantial challenges and costs of proving its case in a Canadian trial. Most important, as Sara Seck argues, Canada should take some responsibility for the action abroad of the significant number of leading multinational mining and oil and gas corporations based in Canada. ${ }^{277}$ These kinds of operations generate significant environmental and health risks and frequently operate in developing economies that often lack significant experience with such operations. A Canadian commitment to responsible internationalism and governance is challenged if there is no effort to take some responsibility in sectors where Canadian business actors are among the most important transnational actors. The allegations against the Talisman oil company of human rights problems related to its oil operations in Sudan are another high-profile example where a Canadian court, faced with a private suit, might be tempted to use forum non conveniens analysis without consideration of broader international contexts. ${ }^{278}$

Transnational tort actions involving developing economies may require a different analysis of questions of jurisdiction. In contrast, there may be no reason to be concerned about effective regulation or legal protections with respect to a transnational tort action relating to the United States for reasons such as the basic public regulatory structures in place, the generally protective purpose of US tort law, the highly developed tort-litigation process, and the economic and political power of the United States in Canada. Indeed, such differences in context might argue for a very different treatment of some Canadian private international law rules with respect to American jurisdictions, as I will attempt to illustrate in the next section.

\section{RECOGNITION AND ENFORCEMENT OF JUDGMENTS:}

THE EXAMPLE OF US PUNITIVE DAMAGE AWARDS

A developing and important issue in the recognition and enforcement of judgments concerns punitive damage awards from the United States. This issue is an example where a Canadian court, following the internationalist policy orientation in the tetralogy, may

277 Seck, supra note 269 .

278 With respect to the complaints concerning Talisman, see, for example, Human Security in Sudan: The Report of a Canadian Assessment Mission, prepared by John Harker for the Minister of Foreign Affairs (Ottawa, January 2000). 
miss important specific concerns of state interests and individual fairness. ${ }^{279}$

The Morguard case involved two Canadian jurisdictions. Although the court identified some distinctively Canadian factors to reinforce its judgment, the basic rationale for the decision was the functional needs of an increasingly interdependent international system and the guiding principle of comity. A number of lower courts have followed this reasoning and applied the Morguard principles to permit recognition and enforcement of judgments from non-Canadian judgments. ${ }^{280}$ In Moses v. Shore Boat Builders Ltd., for example, the British Columbia Court of Appeal applied the Morguard rule to a default judgment of an Alaskan court against a British Columbia defendant. ${ }^{281}$ This approach has been supported by some academic commentators who have observed that the comity arguments in the Morguard case would apply internationally as well as interprovincially and that: "[a]ll aspects of international or interprovincial conflict of laws should be subjected to the same limitation: that there must exist a real and substantial connection to the forum for it to take jurisdiction or to apply its own law, and to have its judgments recognized elsewhere." 282 Yet with respect to US judgments, a number of concerns arise. Lord Denning expressed these concerns most colourfully in his observation that "[a]s a moth to the light, so a litigant is drawn to the United States. If he can only get his case into their courts, he stands to win a fortune."283 Among the many concerns expressed by Lord Denning with respect to US civil litigation, the availability of punitive damages in

${ }^{279}$ A significant recent example of a related debate in the Canada-US context concerns the willingness of Canadian courts perhaps too readily to "complement, coordinate and where appropriate accommodate the proceedings" of US courts in cross-border insolvencies; see Re Babcock \& Wilcox Canada Ltd., (2000) 18 C.B.R. (4th) 157 (Ont. S.C.J. [Commercial List]) at para 9. It evidences the importance of the tetralogy in Canadian law that Justice Farley, the leading judge in Ontario on matters related to cross-border insolvencies, invoked Morguard in his judgment in Babcock and in previous judgments as providing a strong policy support for extending the practice of comity to the international context and to the context of cross-border insolvencies. For critical commentary, see, for example, J. Ziegel, "Corporate Groups and Canada-US Crossborder Insolvencies: Contrasting Judicial Visions" (2000) 25 C.B.R. (4th) 161.

${ }^{280}$ See Blom, supra note 28 , for a survey of cases.

${ }^{281}$ Moses, supra note 238.

282 Castel, supra note 10 at 66.

${ }^{283}$ Smith Kline E' French Laboratories Ltd. v. Bloch (1983), 2 All E.R. 72 at 74 (C.A.). 
combination with jury trials and contingent fee agreements seems to figure foremost.

Under the internationalist interpretation of the Morguard ruling, it would seem that because of the concerns of comity, Canadian courts have little basis on which to conduct detailed reviews of the punitive damages components of US judgments so long as the jurisdiction in question has a real and substantial connection to the matter in dispute. Moreover, such refusals would seem to be an unacceptable parochialism given that Canadian courts also award punitive damages. ${ }^{284}$ However, the argument for liberalized recognition and enforcement of judgments is based on a general convergence in underlying substantive regimes, and the need for international cooperation ignores the degree to which genuine, and relevant, private law conflicts regularly occur between jurisdictions that have similar underlying laws. More attention must be paid to the particular kind of conflict typically in dispute in private international law. Most private international law disputes are not a threat to international system-level concerns. For individual litigants, however, such disputes do involve serious issues of distributive fairness.

The broad emphasis on international cooperation inadequately captures what practically speaking amounts to a substantial policy disagreement between Canadian and American jurisdictions concerning punitive damages policy. The mere shared classification of damages as punitive damages disguises the degree to which substantial differences exist in Canada on the quantum of such damages. For most practical purposes, substantial disputes about differences in quantum are as important as disputes about liability. ${ }^{285}$ The

${ }^{284}$ Canadian courts may award exemplary damages in tort law and, more rarely, in contract; see S. Waddams, The Law of Damages (Toronto: Canada Law Book, 1997) at paras. 11.250-1 1.260. The recent decision of the Supreme Court of Canada in Whiten v. Pilot Insurance Co., 2002 S.C.C. 18 , signals that substantial punitive damages may be available, although "very much the exception rather than the rule" (para. 94), in breach of contract cases in Canada. It is interesting that the court considered submissions concerning the excesses of the US experience with punitive damages in the course of its evaluation of what Canadian law on the issue should be (paras. 6o-65).

${ }^{285}$ The court in Tolofson, supra note 1 at 1059 did not seem to appreciate this; it considered that general convergence in liability principles with respect to guest passenger statutes had diminished public policy problems because only differences in quantum remained. In Kidron v. Grean, (1999) 48 O.R. (3d) 775 (Gen.Div.), leave to appeal refused 48 O.R. (3d) 784 , Justice Brennan suggested a more cautious approach to the recognition and enforcement of a 
significant differences in damage awards could amount to a transfer of resources from one jurisdiction to another. More importantly, the differences may cause hardship to particular defendants who may have acted in reliance on reasonable expectations that did not include potential exposure to such punitive damage awards enforceable in their home jurisdictions.

The quantum of punitive damages in the United States has raised concerns among many of the states engaged in negotiations for a multilateral convention on recognition and enforcement of judgments. ${ }^{286}$ National courts have also been reluctant to give recognition and enforcement to such awards. In an important 1992 decision, for example, the German Bundesgerichtshof recognized and enforced a judgment of a California court with respect to damages under a number of heads but refused to enforce the punitive damages part of the judgment, citing reasons of "public policy."287 Similar approaches have been taken with respect to punitive damages by courts in jurisdictions such as Japan..$^{28}$

The use of a public policy exception with respect to punitive damage awards would be an expansion from the very restricted use of the exception in contemporary conflict of laws in common law jurisdictions, ${ }^{289}$ and would seem to run counter to a regime of expanding international policy values. However, such expansion is a potentially sensible change to accompany a more liberalized regime of recognition and enforcement of judgments.

A good example of the significance of the differences in punitive damages is found in the 1995 judgment of a Mississippi state court

California judgment that included a substantial award for emotional distress damages. The judge seemed particularly concerned about the quantum of the damages awarded in comparison to the caps on recovery of such damages in Canada.

${ }^{286}$ See Weintraub, supra note 86 at $203^{-0} 5$.

${ }^{287}$ Judgment of June 4, 1992, 13 ZIP 1256 (1992), (1993) 32 I.L.M. 1320 . See H. Bungert, "Enforcing U.S. Excessive and Punitive Damages Awards in Germany" (1993) 27 Int'l Lawyer 1075; P. Hay, "The Recognition and Enforcement of American Money-Judgments in Germany - The 1992 Decision of the German Supreme Court" (1992) 40 Am. J. Comp. L. 729; Brand, supra note 166 at 6o8-i3.

288 See, for example, An Oregon Partnership, Northcon Iv. Yoshitaka Katayama; Mansei Kogyo Kabushiki Kaisha, H.J. (1376) 79 [1991], H.T. (760) 250 [1991] (Tokyo District Court, 18 February 1991) reported at (1992) 35 Japanese Annual Int'l L. 177 ; see Brand, supra note 166 at 612 .

Castel, supra note 10 at $171-74$. 
in O'Keefe v. Loewen Group, Inc., et al. ${ }^{290}$ In a jury trial, the Loewen Group, a funeral home company based in Burnaby, Canada, was found to have been in breach of contract in a commercial dispute concerning licenses and negotiations connected to the takeover by Loewen of some funeral homes in Mississippi. The property in dispute involved three contracts valued at US \$1 million and an exchange of funeral homes worth US $\$ 2.5$ million for an insurance property valued at US $\$ 4$ million. The jury awarded US $\$ 1$ oo million in compensatory damages and US $\$ 400$ million in punitive damages. Faced with this award, Loewen sought to appeal. Partly based on a Mississippi rule that required posting of a 125 per cent bond, which in this case would have totalled US $\$ 625$ million, Loewen eventually settled for approximately $\$ 175$ million. Loewen subsequently went into reorganization under bankruptcy laws. In an interesting indication of the convergence of private law and international trade law, Loewen and its founder Ray Loewen have also filed a complaint under the NAFTA investment chapter seeking damages. ${ }^{291}$ Whatever the merits of the Mississippi judgment as the basis for a claim in international trade law, the refusal by a Canadian court of enforcement of some part of the judgment in the Loewen case might have been an appropriate expression of the differences in views between Canada and Mississippi as to the size of awards and the purpose of punishment served by punitive damage awards.

The different scale of punitive damages between the United States and Canada reflects different underlying views of the uses of civil litigation as a tool of regulatory policy and of the purposes of deterrence and punishment. In the United States, civil litigation is an important part of the regulatory framework through a system of countervailing power. The system of "private attorneys general"

290 O'Keefe v. The Loewen Group Inc. et al., 91-67-423 (Cir.Ct, Hinds Co., Miss. 1995).

${ }^{291}$ Loewen v. United States, supra note 187 . The claim was filed under the privateparty investor dispute settlement provisions of Section B, Chapter 11 of NAFTA, supra note 187. The substantive claim is based on Articles 1102,1105 , and 1110 of NAFTA. See "NAFTA Panel Expected to be Constituted Soon in Canadian Firm's $\$ 725$ Million NAFTA Claim" January 20, 1999, BNA Int'l Trade Reporter 81; M. Krauss, "NAFTA Meets the American Torts Process: O'Keefe v. Loewen" (2000) g George Mason. L. Rev. 69. An initial ruling of the panel rejected arguments by the United States on matters of competence and jurisdiction; see The Loewen Group, Inc. and Raymond L. Loewen $v$. United States of America (ICSID Case No. ARB (AF) $/ 98 / 3$ ), Decision of the Arbitral Tribunal on Hearing of Respondent's Objection to Competence and Jurisdiction (January 5,2001 ). 
in areas such as securities regulation and antitrust demonstrate the significance of regulation through private actions in the United States. The US system of antitrust litigation mixes government regulation and private litigation. The award of treble damages is an important part of this system. Treble damages are also available for certain kinds of private actions under the Securities Exchange Act. ${ }^{292}$ The degree to which Canada and US legislators have different views of private litigation and the quantum of damages is reflected in Canadian legislation that permits the "clawback" of such treble damage awards. ${ }^{293}$

From an international trade perspective, the punitive damage awards may themselves be as suspect as the refusal of a foreign court to recognize and enforce such awards. The punitive damage awards may be motivated by parochial dislike of foreigners who conduct business in a jurisdiction. The scale of such awards may also amount to de facto discrimination, in that foreign competitors may either be dissuaded from entry into the local market or forced to take out expensive forms of liability insurance, especially given that they already face public law regulation in their home jurisdictions. More generally, such awards may be economically inefficient in providing over-deterrence, in particular, where they serve a purely punitive, rather than a deterrent, function. Indeed, even within the United States, substantial debate exists as to the utility of punitive damages beyond a certain quantum..$^{294}$

Even under ideas of international cooperation among liberal states, it is not clear that a Canadian jurisdiction should necessarily recognize and enforce judgments with which it disagrees. Slaughter, for example, has written that with respect to the Act of State doctrine national courts should feel less worried about deference

292 Securities Exchange Act of 1934,15 U.S.C. $\$ 78$ (1934).

${ }^{293} \mathrm{See}$, for example, Foreign Extraterritorial Measures Act, supra note 189 ; Castel et al., supra note 71 at $645^{-4} 6$.

${ }^{294}$ Substantial disagreement about punitive damages is reflected in debates within the United States itself. Weintraub observes that in international negotiations concerning the recognition and enforcement of US judgments, "[d]efense of punitive damages will not be helped by the fact that most states have, by statute or decision, placed limits on punitive awards and that the U.S. Supreme Court has held that a 'grossly excessive' award of punitive damages violates due process"; Weintraub, supra note 86 at $182-83$ [notes omitted]. The Mississippi judgment against Loewen features prominently as a chapter in a conservative journalist's book severely criticizing the legal system in the United States; M. Boot, Out of Order: Arrogance, Corruption, and Incompetence on the Bench (New York: Basic Books, 1998) at $15^{8-60 ;}$ see also Krauss, supra note 291. 
to foreign courts of jurisdictions that share common basic values and institutions because there is less risk of ideologically motivated interference with the foreign jurisdiction. ${ }^{295}$ Transjudicial dialogue among the courts of liberal jurisdictions should include the ability to engage in more critical dialogue concerning judgments.

With this understanding, the approach of refusing to enforce some part of a foreign punitive damages award seems like a tailored, compromise solution. A plaintiff is not left with a useless judgment. Most of the other heads of damages, which may be substantial, will be recognized against Canadian assets of the defendant. Often, defendants, especially corporate defendants, have assets in other jurisdictions against which the plaintiff may be able to enforce even the punitive damages component of the judgment. Finally, the plaintiff always has the option of commencing an action in the Canadian jurisdiction if most of the assets are in Canada. The judgment will be enforceable to the full extent in the forum jurisdiction and partly enforceable in the foreign jurisdiction. This seems to be a rough compromise reflecting the fact that both jurisdictions have connections to the matter but disagree as to the applicable results in the dispute. It may also best reflect the legitimate expectations of fairness of both parties to the litigation.

\section{Part 7: CONClusion}

The judgments of the tetralogy have brought the policy dimensions of internationalization clearly into the centre of law-making and adjudication in Canadian private international law. It seems clear that legal actors - including legislators, judges, and practitioners - must master the features of this internationalist discourse in order to make good decisions and to be effective advocates in today's terrain of private international law and other aspects of law, which are impacted by globalization and internationalization.

The danger is that the new discourse of internationalism will be misunderstood as a narrow apology for only a limited kind of doctrinal reform and a narrow definition of the policy purposes of private international law in an era of globalization. There is nothing about any one of the international policy objectives - international commerce, interstate cooperation, or cosmopolitan fairness - that compels ignoring other policy objectives in the field. Indeed, general

295 A-M. Burley, "Law among Liberal States: Liberal Internationalism and the Act of State Doctrine" ( 1992 ) 92 Columbia L. Rev. 1907 at $1975^{-85}$ and 1993. 
policy objectives such as international commerce, interstate cooperation, and cosmopolitan fairness often are indeterminate with respect to particular doctrinal reforms. In order to understand the nature and the limits of internationalist reform better, it is necessary to examine some of the personal, national and historical contexts for such reforms. This article situated the internationalist policy discourse of the tetralogy in the contexts of traditions of liberal internationalism, Canadian internationalism, and the disciplinary internationalism of public international law. By situating the policy discourse in this way, the article attempted to give a better sense of how the openness of internationalist policy justifications can become narrow and be misused to exclude valid policy concerns.

The tetralogy also shows how courts play an active role in constituting the legal terrain of the international system. The judgments show how concepts and ideational orientations about the international realm can lead to concrete results. Hopefully, a critical understanding of the tetralogy will provide a sense of how debates about internationalism can be productively used in debates about private international law and other fields impacted by internationalization. The strengths and limits of the policy argumentation in the tetralogy are symptomatic of other policy debates concerning the global and the international in Canada as elsewhere. For example, recent controversies concerning international trade regulation, such as the defeat of the proposed Multilateral Agreement on Investment, the failures of the 1999 Seattle Ministerial Meeting of the World Trade Organization, and the protests at the 2001 Québec meetings concerning the proposed Free Trade Area of the Americas, indicate substantial resistance to further expansion of the international trading order. This resistance is at least partly a response to a policy focus in international trade regulation on a narrow set of liberal internationalist objectives centred on promoting international commerce, facilitating inter-state relations, and promoting a shallow and economistic conception of non-discrimination. ${ }^{296}$ Moreover, the willingness on the part of governments to suppress critical policy discussion at the APEC meetings in Vancouver in $1997^{297}$ and at the FTAA meetings in Québec may be symptomatic of a

${ }^{296}$ Unfortunately, some such resistance tends toward equally naive antiinternationalist positions rather than carefully articulated policy analysis and response.

${ }^{297}$ See W. Pue, Pepper in Our Eyes: The APEC Affair (Vancouver: UBC Press, 2000). 
narrow policy concept of internationalism. The policy aspects of the internationalist reform of private international law in Canada suggests that being for the international must also be about debating the international.

\section{Sommaire}

Au nom de l'international: La Cour suprême du Canada et la métamorphose internationaliste du droit international privé canadien

Cet article examine quatre arrêts de la Cour suprême du Canada qui ont eu pour effet de transformer le droit international privé au Canada, les présentant comme un épisode remarquable dans l'internationalisation du droit, un genre d'activisme judiciaire au nom de l'international. Selon l'auteur, ces arrêts révèlent un modèle d'internationalisation fondé sur la conscience politique internationaliste, distinct mais souvent complémentaire de l'internationalisation au moyen de traités internationaux et de changements au droit international coutumier. Les traits saillants de cette approche semblent présenter des ressemblances avec les traditions de l'internationalisme libéral, de l'internationalisme canadien et du droit international public. L'article fait une mise en garde contre plusieurs dangers d'ordre général que soulève le recours à cette approche pour la réforme du droit et le raisonnement judiciaire. L'auteur mentionne en particulier deux questions de doctrine en droit international privé afin d'illustrer une approche plus sophistiquée à une politique d'internationalisme.

\section{Summary}

In the Name of the International: The Supreme Court of Canada and the Internationalist Transformation of Canadian Private International Law

This article discusses four judgments of the Supreme Court of Canada that transformed private international law in Canada and represent a striking episode in the internationalization of law - a form of judicial activism in the name of the international. It is argued that these cases evidence a mode of internationalization by internationalist policy consciousness that is distinct from, although often complementary to, internationalization via the mechanism of international treaties or changes in customary international law. The key features of this approach suggest some resemblances to 
the vision found in the traditions of liberal internationalism, Canadian internationalism, and public international law. The article cautions against several general dangers in the use of this approach in law reform and adjudication and uses two specific doctrinal issues in private international law to demonstrate what a richer policy discourse concerning internationalism would be. 